Prepared in cooperation with the San Antonio River Authority and the Texas Water Development Board

Sediment Characteristics in the San Antonio River Basin Downstream From San Antonio, Texas, and at a Site on the Guadalupe River Downstream from the San Antonio River Basin, 1966-2013

Scientific Investigations Repert 2014-5048 
Front cover: Collection of a suspended-sediment sample by hydrologic technicians at U.S. Geological Survey station 08185000 Cibolo Creek at Selma, Texas, on May 25, 2013. The technician in the foreground is using a smart phone to check peak discharge at the site during the flood by accessing http://m.waterdata.usgs.gov (http://waterdata.usgs.gov/nwis on the Web). Photograph by Chiquita Lopez, U.S. Geological Survey.

\section{Back cover:}

Top, Collection of a bedload sample at U.S. Geological Survey station 08186500 Ecleto Creek near Runge, Texas. Photograph by Chiquita Lopez, U.S. Geological Survey.

Bottom, Collection of a suspended-sediment sample from the bridge at U.S. Geological Survey station 08181800 San Antonio River near Elmendorf, Texas. Photograph by Michael Nyman, U.S. Geological Survey. 


\section{Sediment Characteristics in the San Antonio River Basin Downstream From San Antonio, Texas, and at a Site on the Guadalupe River Downstream from the San Antonio River Basin, 1966-2013}

By Cassi L. Crow, J. Ryan Banta, and Stephen P. Opsahl

Prepared in cooperation with the San Antonio River Authority and the Texas Water Development Board

Scientific Investigations Report 2014-5048 


\section{U.S. Department of the Interior \\ SALLY JEWELL, Secretary}

\section{U.S. Geological Survey \\ Suzette M. Kimball, Acting Director}

\section{U.S. Geological Survey, Reston, Virginia: 2014}

For more information on the USGS — the Federal source for science about the Earth, its natural and living resources, natural hazards, and the environment, visit http://www.usgs.gov or call 1-888-ASK-USGS.

For an overview of USGS information products, including maps, imagery, and publications, visit http://www.usgs.gov/pubprod

To order this and other USGS information products, visit http://store.usgs.gov

Any use of trade, firm, or product names is for descriptive purposes only and does not imply endorsement by the U.S. Government.

Although this information product, for the most part, is in the public domain, it also may contain copyrighted materials as noted in the text. Permission to reproduce copyrighted items must be secured from the copyright owner.

Suggested citation:

Crow, C.L., Banta, J.R., and Opsahl, S.P., 2014, Sediment characteristics in the San Antonio River Basin downstream from San Antonio, Texas, and at a site on the Guadalupe River downstream from the San Antonio River Basin, 1966-2013: U.S. Geological Survey Scientific Investigations Report 2014-5048, 33 p., http://dx.doi.org/10.3133/ sir20145048.

ISSN 2328-031X (print) ISSN 2328-0328 (online) ISBN 978-1-4113-3779-4 


\section{Contents}



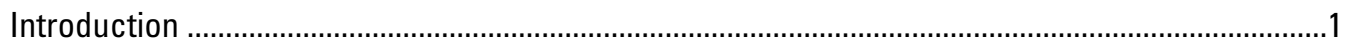

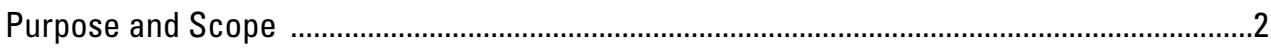

Description of the Study Area ..........................................................................................

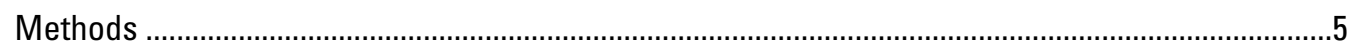

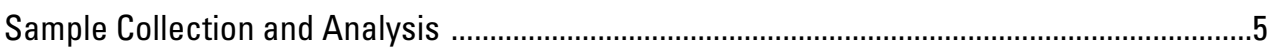

Suspended-Sediment Sample Collection and Laboratory Analysis ...............................5

Bedload Sample Collection and Laboratory Analysis .....................................................

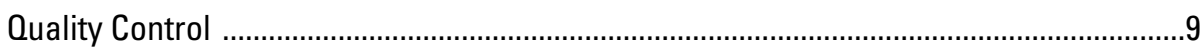

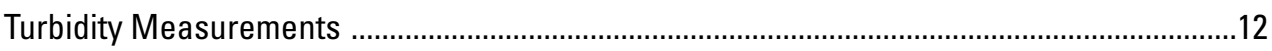

Instantaneous Suspended-Sediment Load, Bedload, and Total Sediment Load ....................12

Estimating Suspended-Sediment Loads from Streamflow .....................................................13

Limitations in Estimating Suspended-Sediment Load from Streamflow ................................13

Estimating Suspended-Sediment Loads from Turbidity ...........................................................14

Sediment Characteristics .................................................................................................

Suspended-Sediment Concentration .............................................................................15

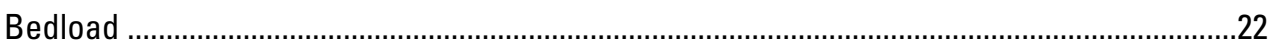



Instantaneous Suspended-Sediment Loads, Bedloads, and Total Loads ............................22

Estimated Daily Suspended-Sediment Loads from Streamflow ..........................................26

Estimated Daily Suspended-Sediment Loads from Turbidity ..................................................29



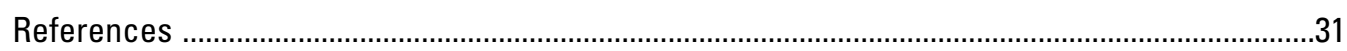

Appendixes

1. Streamflow, suspended-sediment concentrations, and instantaneous suspendedsediment loads at the sample collection sites in the San Antonio River Basin downstream from San Antonio, Texas, and at a site on the Guadalupe River downstream from the San Antonio River Basin, including data prior to 2011.

2. Daily mean streamflow and estimated suspended-sediment loads at sample collection sites in San Antonio River Basin downstream from San Antonio, Texas, and at a site on the Guadalupe River downstream from the San Antonio River Basin, 2011-12.

3. Daily mean turbidity at U.S. Geological Survey station 08181800 San Antonio River near Elmendorf, Texas (SAR Elmendorf), 2010-13.

\section{Figures}

1. Map showing data collection sites in the San Antonio River Basin downstream from San Antonio, Texas, and at a site on the Guadalupe River downstream from the San Antonio River Basin, January 2011 through May 2013

2. Graphs showing daily mean streamflow with sediment sample collection dates and time-series suspended-sediment load estimated from daily mean streamflow and daily suspended-sediment concentration for selected sites in the San Antonio River Basin downstream from San Antonio, Texas, and at a site on the Guadalupe River downstream from the San Antonio River Basin, January 2011-May 2013 
3. Photographs showing samplers used to collect suspended-sediment and bedload samples at sites in the San Antonio River Basin downstream from San Antonio, Texas, and at a site on the Guadalupe River downstream from the San Antonio River Basin, January 2011-May 2013

4. Graph showing distribution of suspended-sediment concentrations at sites in the San Antonio River Basin downstream from San Antonio, Texas, and at a site on the Guadalupe River downstream from the San Antonio River Basin, 1966-2013 .18

5. Graphs showing relations between suspended-sediment concentration and streamflow at sites $A$, SAR Elmendorf site (U.S. Geological Survey [USGS] station 08181800, San Antonio River near Elmendorf, Texas); $B$, SAR Falls City site (USGS station 08183500 San Antonio River near Falls City, Tex.); $C$, Cibolo Falls City site (USGS station 08186000, Cibolo Creek near Falls City, Tex.); $D$, Ecleto Runge site (USGS station 08186500, Ecleto Creek near Runge, Tex.); and $E$, SAR Goliad site (USGS station 08188500 San Antonio River at Goliad, Tex.)

6. Graph showing daily mean turbidity from January 2011 through September 2013 at SAR Elmendorf site (U.S. Geological Survey station 08181800, San Antonio River near Elmendorf, Texas), in formazin nephelometric units (FNU)

7. Graphs showing relation between suspended-sediment concentrations and turbidity at $A$, SAR Elemendorf site (U.S. Geological Survey [USGS] station 08181800 San Antonio River near Elmendorf); $B$, SAR Goliad site (USGS station 08188500 San Antonio River at Goliad); and C, GR Tivoli site (USGS station 08188800 Guadalupe River near Tivoli, Texas)

\section{Tables}

1. The number of historical and 2011-13 sediment samples collected at sites in the San Antonio River Basin downstream from San Antonio, Texas, and at a site on the Guadalupe River downstream from the San Antonio River Basin

2. Relative percent difference for replicate suspended-sediment data from sites sampled in the San Antonio River Basin downstream from San Antonio, Texas, and at a site on the Guadalupe River downstream from the San Antonio River Basin, January 2011-May 2013

3. Suspended-sediment data collected at sites in the San Antonio River Basin downstream from San Antonio, Texas, and at a site on the Guadalupe River downstream from the San Antonio River Basin, January 2011-May 2013, showing the percentage of sand-sized and fine-sized particles in each sample

4. Suspended-sediment data collected at sites in the San Antonio River Basin downstream from San Antonio, Texas, and at a site on the Guadalupe River downstream from the San Antonio River Basin, January 2011-May 2013, showing complete distribution of particle size for each sample.

5. Bedload mass and instantaneous bedload transport for samples collected at sites in the San Antonio River Basin downstream from San Antonio, Texas, and at a site on the Guadalupe River downstream from the San Antonio River Basin, January 2011-May 2013

6. Bedload particle-size distribution for samples collected at sites in the San Antonio River Basin downstream from San Antonio, Texas, and at a site on the Guadalupe River downstream from the San Antonio River Basin, January 2011May 2013

7. Regression equations, average estimated suspended-sediment load, and summary statistics for suspended-sediment concentration regressions 


\section{Conversion Factors}

Inch/Pound to SI

\begin{tabular}{lcl}
\hline & Multiply & To obtain \\
\hline inch (in.) & Length & \\
inch (in.) & 2.54 & centimeter $(\mathrm{cm})$ \\
foot (ft) & 25.4 & millimeter $(\mathrm{mm})$ \\
mile (mi) & 0.3048 & meter $(\mathrm{m})$ \\
\hline & 1.609 & kilometer $(\mathrm{km})$ \\
\hline square mile $\left(\mathrm{mi}^{2}\right)$ & Area & square kilometer $\left.(\mathrm{km})^{2}\right)$ \\
\hline & 2.590 & meter per second $(\mathrm{m} / \mathrm{s})$ \\
\hline foot per second $(\mathrm{ft} / \mathrm{s})$ & Flow rate & cubic meter per second $\left(\mathrm{m}^{3} / \mathrm{s}\right)$ \\
\hline cubic foot per second $\left(\mathrm{ft}^{3} / \mathrm{s}\right)$ & 0.3048 & \\
\hline ton per day (ton $/ \mathrm{d})$ & 0.02832 & metric ton per day \\
ton per day (ton $/ \mathrm{d})$ & Mass & megagram per day $(\mathrm{Mg} / \mathrm{d})$ \\
\hline
\end{tabular}

SI to Inch/Pound

\begin{tabular}{lcc}
\hline Multiply & By & To obtain \\
\hline millimeter $(\mathrm{mm})$ & Length & \\
\hline & 0.03937 & inch (in.) \\
\hline liter $(\mathrm{L})$ & Volume & quart (qt.) \\
\hline & 1.0567 & \\
\hline $\operatorname{gram}(\mathrm{g})$ & Mass & ounce (oz.) \\
\hline
\end{tabular}

Temperature in degrees Celsius $\left({ }^{\circ} \mathrm{C}\right)$ may be converted to degrees Fahrenheit $\left({ }^{\circ} \mathrm{F}\right)$ as follows:

${ }^{\circ} \mathrm{F}=\left(1.8 x^{\circ} \mathrm{C}\right)+32$

Horizontal coordinate information is referenced to the North American Datum of 1983 (NAD 83).

Concentrations of suspended sediment in water are reported in milligrams per liter (mg/L) . 



\title{
Sediment Characteristics in the San Antonio River Basin Downstream From San Antonio, Texas, and at a Site on the Guadalupe River Downstream from the San Antonio River Basin, 1966-2013
}

\author{
By Cassi L. Crow, J. Ryan Banta, and Stephen P. Opsahl
}

\section{Abstract}

San Antonio and surrounding municipalities in Bexar County, Texas, are in a rapidly urbanizing region in the San Antonio River Basin. The U.S. Geological Survey, in cooperation with the San Antonio River Authority and the Texas Water Development Board, compiled historical sediment data collected between 1996 and 2004 and collected suspended-sediment and bedload samples over a range of hydrologic conditions in the San Antonio River Basin downstream from San Antonio, Tex., and at a site on the Guadalupe River downstream from the San Antonio River Basin during 2011-13. In the suspended-sediment samples collected during 2011-13, an average of about 94 percent of the particles was less than 0.0625 millimeter (silt and clay sized particles); the 50 samples for which a complete sediment-size analysis was performed indicated that an average of about 69 percent of the particles was less than 0.002 millimeter. In the bedload samples collected during 2011-13, an average of 51 percent of sediment particles was sand-sized particles in the $0.25-0.5$ millimetersize range. In general, the loads calculated from the samples indicated that bedload typically composed less than 1 percent of the total sediment load. A least-squares log-linear regression was developed between suspended-sediment concentration and instantaneous streamflow and was used to estimate daily mean suspended-sediment loads based on daily mean streamflow. The daily mean suspended-sediment loads computed for each of the sites indicated that during 2011-12, the majority of the suspended-sediment loads originated upstream from the streamflow-gaging station on the San Antonio River near Elmendorf, Tex. A linear regression relation was developed between turbidity and suspendedsediment concentration data collected at the San Antonio River near Elmendorf site because the high-resolution data can facilitate understanding of the complex suspendedsediment dynamics over time and throughout the river basin.

\section{Introduction}

Sediment characteristics including suspended sediment, bedload, particle-size distribution, and turbidity in a river system are important to characterize because data pertaining to sediment characteristics are needed to understand the magnitude and type of sediment transported in a river basin. The magnitude and type of sediment transported in a river basin can affect biological communities (Wood and Armitage, 1997), the concentration and movement of natural constituents and anthropogenic contaminants (Moran and others, 2012; Kemble and others, 2013; Kolpin and others, 2013), and the amount of sediment deposition in coastal environments (Milliman and Meade, 1983). The processes related to sediment transport are complex and dependent on many factors including (1) basin geology; (2) the frequency, magnitude, and duration of storm runoff events; (3) the presence of man-made impoundments or channel modifications; and (4) urban and rural land use in the basin (Leopold, 1997). Sediment transport in streams generally can be categorized as suspended-sediment transport (sediment transported within the water column) and bedload transport (sediment transported along the bottom of the streambed). The complex nature of sediment transport poses challenges in collecting quality sediment data (Edwards and Glysson, 1999). Sediment properties are specific to individual river basins, including the temporal and spatial variability of sediment concentrations and loads, and the particle-size distribution of suspended and bedload sediment. Historical patterns of sediment transport are important for understanding river channel geomorphology and interactions with the flood plain (Leopold, 1997).

The sediment characteristics of the San Antonio River Basin downstream from San Antonio, Tex., are not well understood because relatively little sediment data have been collected. Some historical data were collected prior to 2004. Changes in land use in the study area such as urban development in the greater San Antonio area and development 
activities downstream from San Antonio might increase runoff into streams during storm events. Increases in runoff during storm events can potentially increase the amount and timing of sediment transported into the drainage network, affecting water quality and sediment loads throughout the San Antonio River Basin downstream from San Antonio (Ockerman and McNamara, 2003).

To better understand sediment characteristics in the San Antonio River Basin downstream from San Antonio, the U.S. Geological Survey (USGS), in cooperation with the San Antonio River Authority (SARA) and the Texas Water Development Board (TWDB), collected and analyzed suspended-sediment, bedload, particle-size distribution, and turbidity data over a wide range of hydrologic conditions at sampling sites in the San Antonio River Basin downstream from San Antonio, Tex., and at one site on the Guadalupe River downstream from the San Antonio River Basin from January 2011 through May 2013 and combined that data with the available historical sediment data collected at the same sampling sites. During 2011-13, most sediment samples were collected at USGS streamflow-gaging stations. At two locations, sampling sites were established downstream from streamflow-gaging stations because the bridge where the gaging station was located was deemed unsuitable for sediment sampling (fig. 1).

Turbidity data were collected to develop a basinwide understanding of sediment characteristics and to provide insight into sediment sources and transport dynamics. Because turbidity data are simpler to collect than sediment data, the establishment of the relation between suspended-sediment concentration (SSC) and turbidity in the study area could prove useful for additional investigations.

The presence of dissolved and suspended material (clays, silt, fine organic matter, and other material) in stream water typically results in more turbid (less clear) water (ASTM International, 2007). Turbidity, a measure of water clarity, is often correlated to discrete measurements of SSC and the resulting relation is used as a surrogate for SSC (Rasmussen and others, 2009). Previous studies have demonstrated that during stormflow events, sediment loads often peak prior to the streamflow hydrograph peak (Wood, 1977; VanSickle and Beschta, 1983; Glysson, 1987; Clark and others, 2013). As a result, the suspended-sediment loads (SSL) associated with a certain streamflow value observed during the rising limb of a hydrograph might be different than the loads associated with the same streamflow value observed during the receding limb of the hydrograph. For this reason, turbidity has been theorized to be a better surrogate for predicting SSC than streamflow (Lewis, 1996). Once a strong relation between SSC and turbidity is established for a given river basin, real-time turbidity data can be used to estimate SSC, and high-resolution data from selected sites can be collected to facilitate understanding of the complex suspended-sediment dynamics over time and throughout the river basin.

\section{Purpose and Scope}

Sediment properties in the San Antonio River Basin downstream from San Antonio were characterized by using historical sediment data collected during 1966-2004 and recent sediment data collected during 2011-13. Suspendedsediment and bedload were characterized at 10 sites in the San Antonio River Basin and at 1 site on the Guadalupe River downstream from the San Antonio River Basin. Sixty-seven suspended-sediment samples and 22 bedload samples were collected from January 2011 through May 2013 (hereinafter referred to as 2011-13 samples), and data from these samples were compared with historical suspended-sediment data collected before 2011 (hereinafter referred to as historical samples) at 5 sites sampled during 2011-13. Daily SSLs were estimated during 2011-12; the SSLs were estimated based on regression equations developed between streamflow and SSCs at five sites by using the historical and 2011-13 data. In addition, regression equations between turbidity measurements and suspended-sediment samples were developed at three sites in the San Antonio River Basin.

\section{Description of the Study Area}

The study area consists of 2,150 square miles $\left(\mathrm{mi}^{2}\right)$ of the San Antonio River Basin downstream from San Antonio, Tex., and about $2 \mathrm{mi}^{2}$ of the Guadalupe River Basin downstream from the San Antonio River Basin (fig. 1). The upstream boundary of the study area includes the San Antonio River near Elmendorf, Tex., site (SAR Elmendorf) and the Cibolo Creek at Selma, Tex., site (Cibolo Selma) (map identifiers 1 and 4, respectively, fig. 1 and table 1). The downstream boundary of the study is the Guadalupe River near Rivoli, Tex., site (GR Tivoli) on the Guadalupe River about 1 mile (mi) downstream from the confluence of the San Antonio and Guadalupe Rivers. Cibolo Creek and Ecleto Creek are part of the study area, which encompasses parts of Bexar, Guadalupe, Wilson, Karnes, DeWitt, Goliad, Victoria, and Refugio Counties (fig. 1). The San Antonio River extends about 190 river mi from Elmendorf, Tex., to the confluence of the San Antonio and Guadalupe Rivers. From the upstream boundary of the study area near Selma, Tex., Cibolo Creek extends about 75 river mi downstream to the confluence of Cibolo Creek and the San Antonio River in Karnes County. Ecleto Creek extends about 55 river mi from northern Wilson County to the confluence of Ecleto Creek and the San Antonio River in Karnes County. 




Figure 1. Data collection sites in the San Antonio River Basin downstream from San Antonio, Texas, and at a site on the Guadalupe River downstream from the San Antonio River Basin, January 2011 through May 2013. 
Table 1. The number of historical and 2011-13 sediment samples collected at sites in the San Antonio River Basin downstream from San Antonio, Texas, and at a site on the Guadalupe River downstream from the San Antonio River Basin.

[SSC, suspended-sediment concentration; SSF, suspended-sediment sand-fine break; SSP, suspended-sediment particle-size distribution; BLM, bedload mass; BLP, bedload particle-size distribution; na, not available; USGS, U.S. Geological Survey]

\begin{tabular}{|c|c|c|c|c|c|c|c|c|c|c|}
\hline \multirow{2}{*}{$\begin{array}{l}\text { Map } \\
\text { identifier } \\
\text { (fig. 1) }\end{array}$} & \multirow{2}{*}{$\begin{array}{l}\text { U.S. Geological } \\
\text { Survey station } \\
\text { number }\end{array}$} & \multirow[t]{2}{*}{$\begin{array}{l}\text { U.S. Geological Survey } \\
\text { station name }\end{array}$} & \multirow[t]{2}{*}{$\begin{array}{l}\text { Short name for } \\
\text { sampling site }\end{array}$} & \multirow{2}{*}{$\begin{array}{l}\text { Period of } \\
\text { record } \\
\text { (historical } \\
\text { samples) }\end{array}$} & \multirow{2}{*}{$\begin{array}{l}\text { Period of } \\
\text { record } \\
\text { (2011-13 } \\
\text { samples) }\end{array}$} & \multicolumn{5}{|c|}{$\begin{array}{l}\text { Data type and number of samples } \\
\text { (samples collected prior to 2011/ } \\
\text { samples collected during 2011-13) }\end{array}$} \\
\hline & & & & & & SSC & SSF & SSP & BLM & BLP \\
\hline 1 & 08181800 & $\begin{array}{l}\text { San Antonio River near Elmendorf, } \\
\text { Tex. }\end{array}$ & SAR Elmendorf & 1996-2004 & $2011-12$ & $95 / 10$ & $1 / 3$ & $0 / 7$ & $0 / 6$ & $0 / 1$ \\
\hline 2 & 08183500 & $\begin{array}{l}\text { San Antonio River near Falls City, } \\
\text { Tex. }\end{array}$ & SAR Falls City ${ }^{1}$ & $1966-75$ & na & $48 / 0$ & $2 / 0$ & $7 / 0$ & $0 / 0$ & $0 / 0$ \\
\hline 3 & 08183550 & $\begin{array}{l}\text { San Antonio River at Highway } 181 \\
\text { near Falls City, Tex. }\end{array}$ & SAR Falls City ${ }^{1}$ & na & $2011-12$ & $0 / 9$ & $0 / 2$ & $0 / 7$ & $0 / 0$ & $0 / 0$ \\
\hline 4 & 08185000 & Cibolo Creek at Selma, Tex. & Cibolo Selma & na & $2012-13$ & $0 / 3$ & $0 / 1$ & $0 / 2$ & $0 / 0$ & $0 / 0$ \\
\hline 5 & 08186000 & Cibolo Creek near Falls City, Tex. & Cibolo Falls City & $1967-75$ & $2011-12$ & $36 / 7$ & $1 / 2$ & $6 / 5$ & $0 / 1$ & $0 / 1$ \\
\hline 6 & 08186500 & Ecleto Creek near Runge, Tex. & Ecleto Runge $^{2}$ & $1966-75$ & $2011-12$ & $31 / 3$ & $0 / 0$ & $10 / 3$ & $0 / 1$ & $0 / 1$ \\
\hline 7 & 08186550 & $\begin{array}{l}\text { Ecleto Creek at County Road } 326 \text { near } \\
\text { Runge, Tex. }\end{array}$ & Ecleto Runge $^{2}$ & na & 2012 & $0 / 2$ & $0 / 0$ & $0 / 2$ & $0 / 2$ & $0 / 2$ \\
\hline 8 & 08188060 & $\begin{array}{l}\text { San Antonio River at State Highway } 72 \\
\text { near Runge, Tex. }\end{array}$ & SAR 72 & na & $2011-12$ & $0 / 5$ & $0 / 0$ & $0 / 5$ & $0 / 0$ & $0 / 0$ \\
\hline 9 & 08188500 & San Antonio River at Goliad, Tex. & SAR Goliad & 1974-94 & $2011-12$ & $162 / 8$ & $163 / 2$ & $0 / 6$ & $0 / 3$ & $0 / 1$ \\
\hline 10 & 08188570 & $\begin{array}{l}\text { San Antonio River near McFaddin, } \\
\text { Tex. }\end{array}$ & SAR McFaddin & na & $2011-12$ & $0 / 6$ & $0 / 3$ & $0 / 3$ & $0 / 0$ & $0 / 0$ \\
\hline 11 & 08188800 & Guadalupe River near Tivoli, Tex. & GR Tivoli & na & $2011-12$ & $0 / 14$ & $0 / 4$ & $0 / 10$ & $0 / 9$ & $0 / 4$ \\
\hline
\end{tabular}

'For analysis, data collected at USGS station numbers 08183500 and 08183550 were combined and reported under short name "SAR Falls City."

${ }^{2}$ For analysis, data collected at USGS station numbers 08186500 and 08186550 were combined and reported under short name "Ecleto Runge." 
The northern part of the study area overlies the EdwardsTrinity aquifer system. The remainder of the study area overlies the Texas Coastal Uplands and Coastal Lowlands aquifer systems (Ryder, 1996) (fig. 1). The Cretaceous-age rocks of the Edwards-Trinity aquifer system primarily consist of limestone and sandstone (Ashworth and Hopkins, 1995). The Texas Coastal Uplands aquifer system is composed of formations of Paleocene and Oligocene age, with the sediments (in order of dominance) consisting mostly of sand, silt, and clay, distributed as relatively uniform sequences of predominantly fine- or coarse-grained material (Ryder, 1996). The Texas Coastal Lowlands aquifer system is composed of younger formations from Oligocene through Holocene age that dip and thicken towards the Gulf of Mexico, with sediments that exist in complex, overlapping mixtures of sand, silt, and clay as a result of numerous oscillations of ancient shorelines (Kasmarek and Robinson, 2004; Lizárraga and Ockerman, 2010).

Topography, land cover, precipitation, and population can affect sediment characteristics in the study area. The study area is composed of gently sloping, rolling terrain; the coastal uplands are somewhat more dissected and rolling compared to the coastal lowlands (Ryder, 1996). The land cover consists mostly of brush and grassland (Multi-Resolution Land Characteristics Consortium, 2013), and average annual precipitation ranges from about 30 inches in the northern sections of the basin to about 40 inches in the southern sections of the basin near the coast (National Oceanic and Atmospheric Administration, 2013). San Antonio, the seventh most populous city in the Nation (U.S. Census Bureau, 2012), was founded on the headwaters of the San Antonio River. The population of San Antonio grew by 35 percent from 1990 to 2010 (U.S. Census Bureau, 2012).

\section{Methods}

Historical suspended-sediment data collected between 1966 and 2004 were compiled for use with the 2011-13 suspended-sediment and bedload data. Historical data were collected for various periods at each site ranging from about 10 to 21 years. The historical and 2011-13 data were collected by the USGS at sites in the study area (fig. 1; table 1). In this report, each site is referred to by its map identifier and short name. All sampling sites were located at USGS stream-gaging stations with the exception of two sites sampled during 2011-13-USGS stations 08183550 and 08186550 . For analysis, data collected at USGS stations 08183500 and 08183550 were combined and reported under the short name "SAR Falls City." Similarly, data collected at USGS stations 08186500 and 08186550 were combined and reported under the short name "Ecleto Runge" (table 1).

\section{Sample Collection and Analysis}

During 2011-13, samples of suspended sediment were collected at 10 sites (map identifiers 1 and 3-11; fig. 1; table 1) for the analysis of SSC and particle-size distribution. In addition, samples of bedload material were collected at six sites (map identifiers 1, 5, 6, 7, 9, and 11; fig. 1; table 1) for the analysis of bedload mass and particle-size distribution. Suspended-sediment samples were collected over a range of streamflows ranging from a minimum instantaneous streamflow of 1.9 cubic feet per second $\left(\mathrm{ft}^{3} / \mathrm{s}\right)$ at the Cibolo Selma site (map identifier 4, fig. 1; table 1) on September 17,2012 , to a maximum instantaneous streamflow of 10,600 $\mathrm{ft}^{3} / \mathrm{s}$ at the same site on May 25, 2013 (fig. 2). Note that the streamflow plotted in figure 2 is the daily mean streamflow for each site in cubic feet per second, but the streamflow associated with each sample is the instantaneous streamflow recorded at the time the sample was collected.

\section{Suspended-Sediment Sample Collection and Laboratory Analysis}

Suspended-sediment samples were collected during 2011-13 following standard USGS methods described in Edwards and Glysson (1999). At each sampling site, samples were collected at a minimum of 10 equal-width increments across the stream by using samplers designed to allow water to enter the sampler with no change in velocity or direction as it entered the sampler from the stream, a method referred to as isokinetic sampling. When stream depths were shallow enough to be waded, samples were collected using a US DH-81 1-liter bottle sampler (Davis, 2005) attached to a wading rod (fig. 3). When the stream was too deep to be waded, samples were collected from a bridge using a US DH-2 1-liter collapsible bag sampler (Davis, 2005) attached to a reel and crane system (fig. 3). Samples collected using the US DH-81 sampler at streamflow velocities less than 1.5 feet per second (ft/s) and samples collected using the US DH-2 sampler at velocities less than $2.0 \mathrm{ft} / \mathrm{s}$ were labeled as grab samples because the samplers are unable to collect isokinetic samples at or less than those velocities. Samples were composited into a 14-liter polyethylene churn splitter, and representative suspendedsediment samples were dispensed from the churn splitter into 3 -liter polypropylene bottles. The churn splitter method can potentially bias results when sand-sized (greater than or equal to 0.0625 millimeter [mm]) particles are present in suspendedsediment samples because the heavier sand-sized particles might not remain uniformly suspended in the churn (Capel and Larson, 1995; Horowitz and others, 1997). This potential bias was not expected to substantially influence samples because historical data from sites in the study area indicate the system is dominated by suspended particle sizes much less than $0.0625 \mathrm{~mm}$, even during stormflow events. 


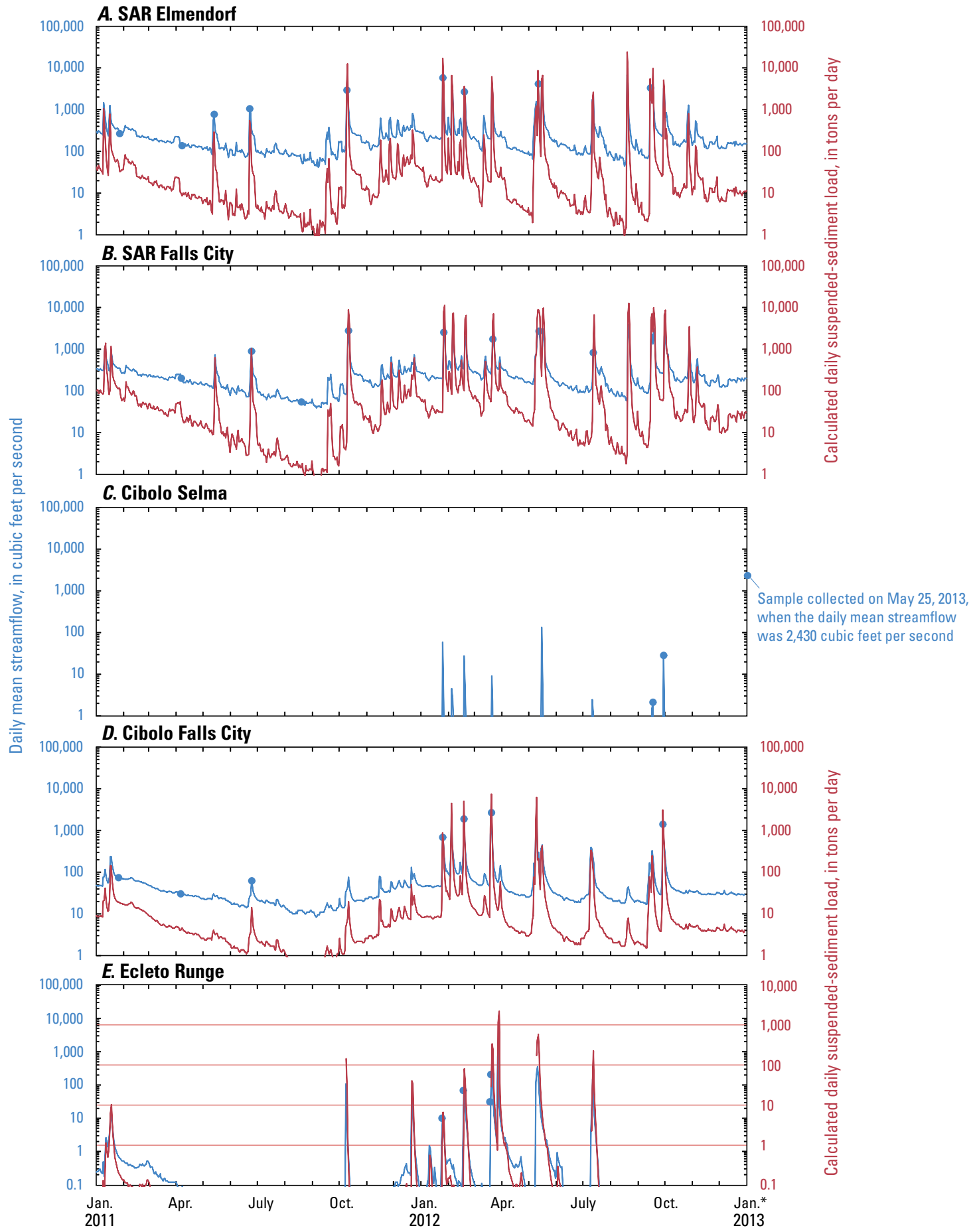

*Except where noted

Figure 2. Daily mean streamflow with sediment sample collection dates and time-series suspended-sediment load estimated from daily mean streamflow and daily suspended-sediment concentration (from U.S. Geological Survey, 2013) for selected sites in the San Antonio River Basin downstream from San Antonio, Texas, and at a site on the Guadalupe River downstream from the San Antonio River Basin, January 2011-May 2013. A, SAR Elmendorf site (U.S. Geological Survey [USGS] station 08181800, San Antonio River near Elmendorf, Tex.); B, SAR Falls City site (USGS station 08183500 San Antonio River near Falls City, Tex.); C, Cibolo Selma site (USGS station 08185000, Cibolo Creek at Selma, Tex.); D, Cibolo Falls City site (USGS station 08186000, Cibolo Creek near Falls City, Tex.); E, Ecleto Runge site (USGS station 08186500, Ecleto Creek near Runge, Tex.); F, SAR 72 site (USGS station 08188060, San Antonio River at State Highway 72 near Runge, Tex.); G, SAR Goliad site (USGS station 08188500 San Antonio River at Goliad, Tex.); H, SAR McFaddin site (USGS station 08188570, San Antonio River near McFaddin, Tex.); I, GR Tivoli site (USGS station 08188800, Guadalupe River near Tivoli, Tex.) 


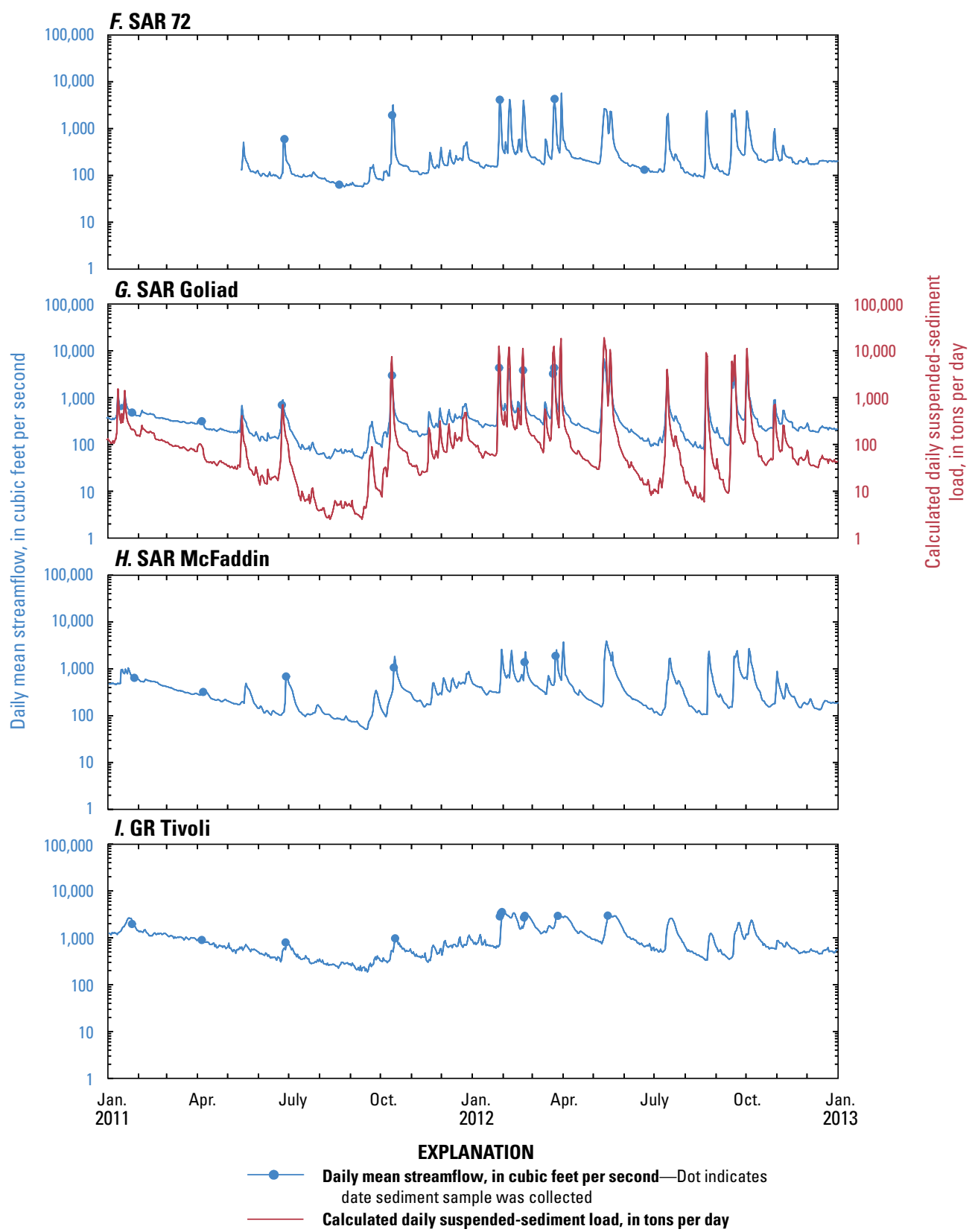

Note: Short names for sampling sites (table 1) are listed above the upper left corners of figures $2 A-21$. For analysis, data collected at USGS station numbers 08186500 and 08186550 were combined and reported under short name "Ecleto Runge."

Figure 2. Daily mean streamflow with sediment sample collection dates and time-series suspended-sediment load estimated from daily mean streamflow and daily suspended-sediment concentration (from U.S. Geological Survey, 2013) for selected sites in the San Antonio River Basin downstream from San Antonio, Texas, and at a site on the Guadalupe River downstream from the San Antonio River Basin, January 2011-May 2013. A, SAR Elmendorf site (U.S. Geological Survey [USGS] station 08181800, San Antonio River near Elmendorf, Tex.); B, SAR Falls City site (USGS station 08183500 San Antonio River near Falls City, Tex.); C, Cibolo Selma site (USGS station 08185000, Cibolo Creek at Selma, Tex.); $D$, Cibolo Falls City site (USGS station 08186000, Cibolo Creek near Falls City, Tex.); E, Ecleto Runge site (USGS station 08186500, Ecleto Creek near Runge, Tex.); F, SAR 72 site (USGS station 08188060, San Antonio River at State Highway 72 near Runge, Tex.); G, SAR Goliad site (USGS station 08188500 San Antonio River at Goliad, Tex.); H, SAR McFaddin site (USGS station 08188570, San Antonio River near McFaddin, Tex.); I, GR Tivoli site (USGS station 08188800, Guadalupe River near Tivoli, Tex.)—Continued 

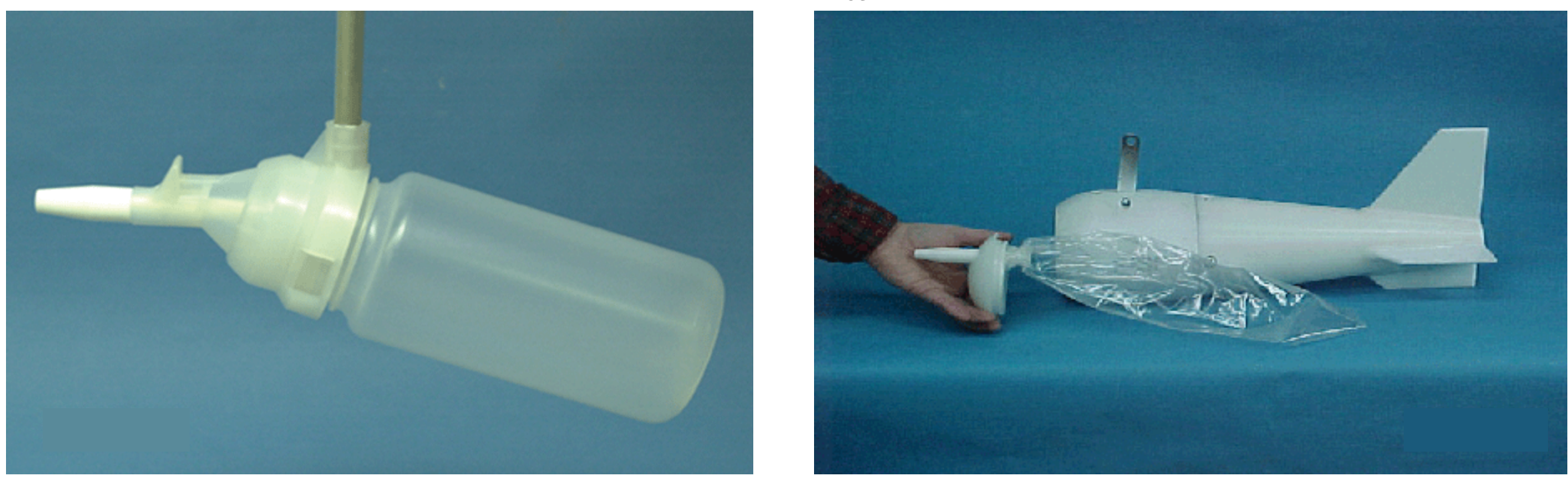

\section{US BL-84}


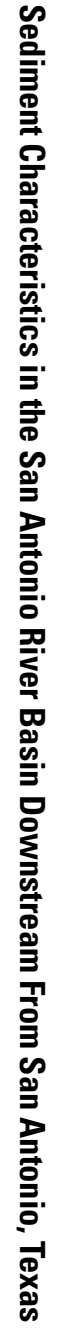

Figure 3. Samplers used to collect suspended-sediment and bedload samples at sites in the San Antonio River Basin downstream from San Antonio, Texas, and at a site on the Guadalupe River downstream from the San Antonio River Basin, January 2011-May 2013. A, US DH-81; B, US DH-2; C, US BLH-84; and D, US BL-84; modified from Davis (2005). 
Suspended-sediment samples were analyzed at the USGS Kentucky Water Science Center Sediment Laboratory in Louisville, Ky., by using methods described in Guy (1969) and in accordance with the quality assurance plan documented in Shreve and Downs (2005). All 67 suspended-sediment samples were analyzed by using filtration or evaporation methods and reported in milligrams per liter $(\mathrm{mg} / \mathrm{L})$. Seventeen suspended-sediment samples were analyzed to determine the percentage of particles less than $0.0625 \mathrm{~mm}$, which generally corresponds to the particle size separating sand-sized ( 0.0625 to $2.0 \mathrm{~mm}$ in diameter) particles from finer-size particles of silts and clays (less than $0.0625 \mathrm{~mm}$ in diameter), commonly referred to as the sand/fine break (Guy, 1969). The sand/fine break analysis was done using a process known as wet-sieving filtration where the sample was washed through a wetted $0.0625-\mathrm{mm}$ mesh sieve. The sand/ fine break data were reported as the percentage of sediment less than $0.0625 \mathrm{~mm}$. The remaining 50 suspended-sediment samples were analyzed to determine the amount of sediment distributed between 11 size classes ranging from less than 0.002 to $2 \mathrm{~mm}$ in diameter (commonly referred to as particlesize distribution). Particle-size distribution analyses were done using a combination of sieve, visual-accumulation tube, and pipet methods as described by Guy (1969) and by Shreve and Downs (2005). Particle-size distributions in suspendedsediment samples were reported as the percentage of sediment less than $0.002,0.004,0.008,0.016,0.031,0.0625,0.125$, $0.25,0.5,1$, and $2 \mathrm{~mm}$.

\section{Bedload Sample Collection and Laboratory Analysis}

Bedload samples were collected using standard USGS methods as described in Edwards and Glysson (1999). Samples were collected using pressure-difference samplers fitted with mesh bags designed to capture sediment moving along the streambed (bedload sediment) while allowing water to pass through the bag. As bedload sediment collected in the bag, the size of the mesh openings decreased, resulting in the collection of particle sizes less than the mesh size of the sample bag $(0.25 \mathrm{~mm})$ (Hubbell, 1964). When stream depths were shallow enough to be waded, a US BLH-84 sampler (Davis, 2005) attached to a wading rod was used to collect bedload samples (fig. 3). When the stream was too deep to be waded, bedload samples were collected using a US BL-84 sampler (Davis, 2005) attached to a reel and crane system (fig. 3). Depending on the site and hydrologic conditions, the bedload sampler rested on the streambed at 20-40 equal-width increments across the stream for a period of 1-2 minutes each, resulting in a composited sample with total collection times of 32-80 minutes.

Bedload samples were analyzed at the USGS sediment laboratory in Louisville, Ky., for total mass and particlesize distribution. In accordance with methods described by Guy (1969), samples were sieved to determine particle sizes ranging from less than 0.0625 to less than $16 \mathrm{~mm}$ in diameter. Quality assurance procedures documented in Shreve and Downs (2005) were followed during the analyses. Total mass for 22 bedload samples was determined by using the evaporation method described in Guy (1969) and reported in grams ( $\mathrm{g}$ ) of dry mass. Ten of the 22 bedload samples were analyzed for particle-size distribution by dry-sieving followed by a combination of sieve, visual-accumulation tube-pipet, and sieve-pipet methods (Guy, 1969). Particlesize distributions in bedload samples were reported as the percentage of sediment less than $0.0625,0.125,0.25,0.5,1,2$, $4,8,16$, and $32 \mathrm{~mm}$.

\section{Quality Control}

Six replicate suspended-sediment samples (table 2) were collected from four sites to evaluate potential bias and variability introduced during sample processing or laboratory analysis. Replicate samples were split from the same churn and compared to the associated environmental samples by calculating the relative percent difference (RPD) for each sample pair of detected constituents (table 2). RPD was computed using the equation:

$$
R P D=|C 1-C 2| /[(C 1+C 2) / 2] \times 100,
$$

where

$$
\begin{aligned}
& \text { C1 is the concentration or percentage from the } \\
& \text { environmental sample; and } \\
& \text { C2 is the concentration or percentage from the } \\
& \text { replicate sample. }
\end{aligned}
$$

The median RPD for SSC was 4.0 percent for the six sample pairs, and 1.1 percent for the particle-size distribution. RPDs exceeded 15 percent for one SSC sample pair and two particle-size distribution pairs, which indicates that bias might have been introduced to these three results during sample collection and processing (for example, while splitting the sample with a churn splitter as previously described in this section) or during laboratory analysis. 
Table 2. Relative percent difference for replicate suspended-sediment data from sites sampled in the San Antonio River Basin downstream from San Antonio, Texas, and at a site on the Guadalupe River downstream from the San Antonio River Basin, January 2011-May 2013.

[mg/L, milligrams per liter; mm, millimeter; Env, environmental sample; Rep, replicate sample; --, not measured; RPD, relative percent difference; nc, not computed]

\begin{tabular}{|c|c|c|c|c|c|c|c|c|c|c|c|}
\hline $\begin{array}{c}\text { U.S. Geological } \\
\text { Survey station } \\
\text { number }\end{array}$ & $\begin{array}{l}\text { U.S. Geological Survey } \\
\text { station name }\end{array}$ & $\begin{array}{l}\text { Short name for } \\
\text { sampling site } \\
\text { (table 1) }\end{array}$ & $\begin{array}{l}\text { Sample } \\
\text { date }\end{array}$ & $\begin{array}{c}\text { Sample } \\
\text { start } \\
\text { time }\end{array}$ & $\begin{array}{l}\text { Sample } \\
\text { type }\end{array}$ & $\begin{array}{c}\text { Suspended } \\
\text { sediment } \\
\text { concentration } \\
\text { (mg/L) }\end{array}$ & $\begin{array}{c}\text { Suspended } \\
\text { sediment } \\
\text { (percent } \\
\text { less than } \\
0.002 \mathrm{~mm} \text { ) }\end{array}$ & $\begin{array}{l}\text { Suspended } \\
\text { sediment } \\
\text { (percent } \\
\text { less than } \\
0.004 \mathrm{~mm} \text { ) }\end{array}$ & $\begin{array}{c}\text { Suspended } \\
\text { sediment } \\
\text { (percent } \\
\text { less than } \\
0.008 \mathrm{~mm} \text { ) }\end{array}$ & $\begin{array}{c}\text { Suspended } \\
\text { sediment } \\
\text { (percent } \\
\text { less than } \\
0.016 \mathrm{~mm} \text { ) }\end{array}$ & $\begin{array}{c}\text { Suspended } \\
\text { sediment } \\
\text { (percent } \\
\text { less than } \\
0.031 \mathrm{~mm} \text { ) }\end{array}$ \\
\hline \multirow[t]{3}{*}{08181800} & $\begin{array}{l}\text { San Antonio River near } \\
\text { Elmendorf, Tex. }\end{array}$ & SAR Elmendorf & $6 / 22 / 2011$ & 1900 & Env & 625 & 60 & 73 & 87 & 93 & 94 \\
\hline & & & & 1905 & Rep & 531 & -- & -- & -- & -- & -- \\
\hline & & & & & RPD & 16.3 & $\mathrm{nc}$ & $\mathrm{nc}$ & $\mathrm{nc}$ & $\mathrm{nc}$ & $\mathrm{nc}$ \\
\hline \multirow[t]{3}{*}{08181800} & $\begin{array}{l}\text { San Antonio River near } \\
\text { Elmendorf, Tex. }\end{array}$ & SAR Elmendorf & $2 / 18 / 2012$ & 1130 & Env & 1,430 & 62 & 69 & 74 & 79 & 88 \\
\hline & & & & 1230 & Rep & 1,420 & 62 & 69 & 75 & 81 & 88 \\
\hline & & & & & RPD & 0.7 & 0 & 0 & 1.3 & 2.5 & 0 \\
\hline \multirow[t]{3}{*}{08186500} & $\begin{array}{l}\text { Ecleto Ck near Runge, } \\
\text { Tex. }\end{array}$ & Ecleto Runge & $3 / 21 / 2012$ & 1030 & Env & 789 & 97 & 99 & 100 & -- & -- \\
\hline & & & & 1035 & Rep & 760 & 96 & 97 & 99 & 99 & 99 \\
\hline & & & & & RPD & 3.7 & 1.0 & 2.0 & 1.0 & $\mathrm{nc}$ & $\mathrm{nc}$ \\
\hline \multirow[t]{3}{*}{08188500} & $\begin{array}{l}\text { San Antonio River at } \\
\text { Goliad, Tex. }\end{array}$ & SAR Goliad & $10 / 13 / 2011$ & 945 & Env & 1,690 & 58 & 77 & 81 & 87 & 89 \\
\hline & & & & 1000 & Rep & 1,620 & 73 & 81 & 86 & 91 & 95 \\
\hline & & & & & RPD & 4.2 & 23 & 5.1 & 6.0 & 4.5 & 6.5 \\
\hline \multirow[t]{3}{*}{08188500} & $\begin{array}{l}\text { San Antonio River at } \\
\text { Goliad, Tex. }\end{array}$ & SAR Goliad & $3 / 23 / 2012$ & 1200 & Env & 1,450 & 81 & 84 & 88 & 90 & 92 \\
\hline & & & & 1235 & Rep & 1,330 & 67 & 80 & 89 & 96 & 97 \\
\hline & & & & & RPD & 8.6 & 19 & 4.9 & 1.1 & 6.5 & 5.3 \\
\hline \multirow[t]{3}{*}{08188800} & $\begin{array}{l}\text { Guadalupe River near } \\
\text { Tivoli, Tex. }\end{array}$ & GR Tivoli & $2 / 23 / 2012$ & 1020 & Env & 317 & 89 & 93 & 96 & 97 & 98 \\
\hline & & & & 1118 & Rep & 322 & 89 & 92 & 96 & 97 & 98 \\
\hline & & & & & RPD & 1.6 & 0 & 1.1 & 0 & 0 & 0 \\
\hline
\end{tabular}


Table 2. Relative percent difference for replicate suspended-sediment data from sites sampled in the San Antonio River Basin downstream from San Antonio, Texas, and at a site on the Guadalupe River downstream from the San Antonio River Basin, January 2011-May 2013._Continued

[mg/L, milligrams per liter; mm, millimeter; Env, environmental sample; Rep, replicate sample; --, not measured; RPD, relative percent difference; nc, not computed]

\begin{tabular}{|c|c|c|c|c|c|c|c|c|c|c|c|}
\hline $\begin{array}{c}\text { U.S. Geological } \\
\text { Survey station } \\
\text { number }\end{array}$ & $\begin{array}{l}\text { U.S. Geological Survey } \\
\text { station name }\end{array}$ & $\begin{array}{l}\text { Short name for } \\
\text { sampling site } \\
\text { (table 1) }\end{array}$ & $\begin{array}{l}\text { Sample } \\
\text { date }\end{array}$ & $\begin{array}{c}\text { Sample } \\
\text { start } \\
\text { time }\end{array}$ & $\begin{array}{l}\text { Sample } \\
\text { type }\end{array}$ & $\begin{array}{c}\text { Suspended } \\
\text { sediment } \\
\text { (percent } \\
\text { less than } \\
0.0625 \mathrm{~mm} \text { ) }\end{array}$ & $\begin{array}{c}\text { Suspended } \\
\text { sediment } \\
\text { (percent } \\
\text { less than } \\
0.125 \mathrm{~mm} \text { ) }\end{array}$ & $\begin{array}{c}\text { Suspended } \\
\text { sediment } \\
\text { (percent } \\
\text { less than } \\
0.25 \mathrm{~mm} \text { ) }\end{array}$ & $\begin{array}{c}\text { Suspended } \\
\text { sediment } \\
\text { (percent } \\
\text { less than } \\
0.5 \mathrm{~mm} \text { ) }\end{array}$ & $\begin{array}{l}\text { Suspended } \\
\text { sediment } \\
\text { (percent } \\
\text { less than } \\
1 \mathrm{~mm} \text { ) }\end{array}$ & $\begin{array}{l}\text { Suspended } \\
\text { sediment } \\
\text { (percent } \\
\text { less than } \\
2 \mathrm{~mm} \text { ) }\end{array}$ \\
\hline \multirow[t]{3}{*}{08181800} & $\begin{array}{l}\text { San Antonio River near } \\
\text { Elmendorf, Tex. }\end{array}$ & SAR Elmendorf & $6 / 22 / 2011$ & 1900 & Env & 96 & 98 & 99 & 100 & -- & -- \\
\hline & & & & 1905 & Rep & 99 & -- & -- & -- & -- & -- \\
\hline & & & & & RPD & 3.1 & $\mathrm{nc}$ & nc & $\mathrm{nc}$ & -- & -- \\
\hline \multirow[t]{3}{*}{08181800} & $\begin{array}{l}\text { San Antonio River near } \\
\text { Elmendorf, Tex. }\end{array}$ & SAR Elmendorf & $2 / 18 / 2012$ & 1130 & Env & 92 & 98 & 100 & -- & -- & -- \\
\hline & & & & 1230 & Rep & 93 & 98 & 100 & -- & -- & -- \\
\hline & & & & & RPD & 1.1 & 0 & 0 & nc & -- & -- \\
\hline \multirow[t]{3}{*}{08186500} & $\begin{array}{l}\text { Ecleto Ck near Runge, } \\
\text { Tex. }\end{array}$ & Ecleto Runge & $3 / 21 / 2012$ & 1030 & Env & -- & -- & -- & -- & -- & -- \\
\hline & & & & 1035 & Rep & 99 & 100 & -- & -- & -- & -- \\
\hline & & & & & RPD & $\mathrm{nc}$ & $\mathrm{nc}$ & $\mathrm{nc}$ & $\mathrm{nc}$ & -- & -- \\
\hline \multirow[t]{3}{*}{08188500} & $\begin{array}{l}\text { San Antonio River at } \\
\text { Goliad, Tex. }\end{array}$ & SAR Goliad & $10 / 13 / 2011$ & 945 & Env & 92 & 95 & 98 & 100 & -- & -- \\
\hline & & & & 1000 & Rep & 95 & 97 & 99 & 100 & -- & -- \\
\hline & & & & & RPD & 3.2 & 2.1 & 1.0 & 0 & -- & -- \\
\hline \multirow[t]{3}{*}{08188500} & $\begin{array}{l}\text { San Antonio River at } \\
\text { Goliad, Tex. }\end{array}$ & SAR Goliad & $3 / 23 / 2012$ & 1200 & Env & 95 & 96 & 98 & 100 & -- & -- \\
\hline & & & & 1235 & Rep & 97 & 98 & 99 & 100 & -- & -- \\
\hline & & & & & RPD & 2.1 & 2.1 & 1.0 & 0 & -- & -- \\
\hline \multirow[t]{3}{*}{08188800} & $\begin{array}{l}\text { Guadalupe River near } \\
\text { Tivoli, Tex. }\end{array}$ & GR Tivoli & $2 / 23 / 2012$ & 1020 & Env & 98 & 99 & 100 & -- & -- & -- \\
\hline & & & & 1118 & Rep & 99 & 99 & 100 & -- & -- & -- \\
\hline & & & & & RPD & 1.0 & 0 & 0 & $\mathrm{nc}$ & -- & -- \\
\hline
\end{tabular}




\section{Turbidity Measurements}

Turbidity, the measure of water clarity, was measured from January 6, 2011, through September 30, 2013, at the SAR Elmendorf site (map identifier 1; fig. 1; table 1) by using a YSI 6920 multi-sensor water-quality monitor equipped with a YSI 6136 optical turbidity sensor (Xylem Analytics, 2014a). Turbidity was measured at the time of sample collection from the centroid of the stream. In addition, a real-time turbidity probe was deployed and measured turbidity every 15 minutes that was recorded by a data-collection platform (DCP) and transmitted to the USGS's National Water Information System (NWIS) database (U.S. Geological Survey, 2013) every hour. The monitor was cleaned and calibrated, and the data were processed following methods described by Wagner and others (2006). The time between visits for cleaning and calibration ranged from 6 to 32 days with an average time between visits of about 18 days. Turbidity sensor calibration occurred in a laboratory environment and consisted of a visual inspection of the probe to ensure the wiper used to clean the optical surface of the probe was parking in the correct location in relation to the optical surface, replacement of the wiper pad, and a two-point calibration using deionized water as a 0 formazin nephelometric unit (FNU) standard and a commercial 100 FNU formazin standard. The YSI 6136 optical turbidity sensor has a reported range of 0 to 1,000 FNU (Xylem Analytics, 2014b); field measurements indicate that the sensor reaches a maximum at approximately 1,100-1,200 FNU, depending on the individual sensor. The accuracy of YSI 6136 optical turbidity sensor is plus or minus 2 percent of the reading or $0.3 \mathrm{FNU}$, whichever is greater (Xylem Analytics, 2014b). Additionally, turbidity measurements made prior to May 23, 2012 , were affected by a programming problem in the DCP that caused turbidity measurements greater than $330 \mathrm{FNU}$ to be recorded as $330 \mathrm{FNU}$. Daily mean turbidity values were calculated from the 15 -minute turbidity measurements. Missing daily mean turbidity values represent days in which 17 or more 15 -minute turbidity measurements (about 18 percent) were missing from the daily record. In this instance, daily mean turbidity values were not computed or reported. The time-series turbidity data described in this report are available from the USGS NWIS (U.S. Geological Survey, 2013).

\section{Instantaneous Suspended-Sediment Load, Bedload, and Total Sediment Load}

Streams transport sediment by maintaining the finer particles in suspension with turbulent currents (SSL) and by intermittent entrainment and movement of coarser particles along the streambed (bedload) (Ellison and others, 2014). Instantaneous streamflow data were obtained from stagedischarge rating curves at the streamflow-gaging station (Rantz and others,1982; Turnipseed and Sauer, 2010) where suspended-sediment samples were collected or at the streamflow-gaging station directly upstream from the sample site (as was the case for the SAR Falls City and Ecleto Runge sites). The SSL transported by the stream past a site at the time of sample collection (hereinafter referred to as instantaneous SSL) was estimated using equation 2 (modified from Porterfield, 1972):

$$
S S L=Q_{i} \times S S C \times k,
$$

where

$$
\begin{aligned}
& S S L \text { is the suspended-sediment load, in tons } \\
& \text { per day; }
\end{aligned}
$$

Bedload refers to the sediment transported by rolling, saltating, or bouncing along a riverbed or the component of sediment in transport from the surface of the riverbed up to the height of the top of the sampler nozzle (Galloway and others, 2013). The bedload transported past a sampled site at the time of sampling (hereinafter referred to as instantaneous bedload) was calculated by using equation 3 (modified from Edwards and Glysson, 1999):

$$
B L=K \times\left(W_{\mathrm{T}} / t_{\mathrm{T}}\right) \times M_{\mathrm{T}}
$$

where

$$
\begin{gathered}
B L \quad \begin{array}{c}
\text { is the instantaneous bedload mass, in tons per } \\
\text { day; }
\end{array} \\
K \quad \begin{array}{c}
\text { is a unit conversion factor ( } 0.381 \text { for a 3-inch } \\
\text { wide nozzle); }
\end{array} \\
W_{\mathrm{T}} \quad \begin{array}{l}
\text { is the total width of the stream, in feet, and } \\
\text { is equal to the increment width multiplied } \\
\text { by the total number of vertical samples } \\
\text { measured in the stream cross section; }
\end{array} \\
t_{\mathrm{T}} \quad \begin{array}{l}
\text { is the total time the sampler remained on the } \\
\text { streambed, in seconds, and is equal to the } \\
\text { sample time multiplied by the total number } \\
\text { of verticals from which samples were } \\
\text { collected; and }
\end{array} \\
\begin{array}{l}
\text { is the total mass of sample collected from } \\
\text { all verticals sampled in the stream cross } \\
\text { section, in grams. }
\end{array}
\end{gathered}
$$

Instantaneous total sediment load for a site, reported in tons per day, was calculated by summing the instantaneous SSL and instantaneous bedload. Instantaneous total sediment load was calculated for 21 sampling events at six sites for which both an instantaneous SSL and an instantaneous bedload were computed. 


\section{Estimating Suspended-Sediment Loads from Streamflow}

To estimate SSLs for days when suspended-sediment samples were not collected, log-linear regressions were developed to estimate SSCs based on streamflow for the five sites for which sufficient data were available (SAR Elmendorf, SAR Falls City, Cibolo Falls City, Ecleto Runge, and SAR Goliad). The historical (appendix 1) and the 2011-13 data were included in the regression analyses. The measured SSC and instantaneous streamflow data were nonnormally distributed and, consequently, were log transformed before the regression lines were calculated. The regression equation for estimating SSC (retransformed into original units incorporating the bias correction factor [Helsel and Hirsch, 2002]) from streamflow is represented as:

$$
S S C=\beta_{0} \times Q_{d}^{\beta 1} \times \Phi
$$

where

$$
\begin{aligned}
\text { SSC } & \begin{array}{r}
\text { is estimated suspended-sediment } \\
\text { concentration, in milligrams per liter; }
\end{array} \\
\beta_{0} \text { and } \beta_{1} & \text { are regression coefficients; } \\
Q_{d} & \text { is the daily mean streamflow, in cubic feet per } \\
& \text { second; and } \\
\Phi & \text { is the bias-correction factor. }
\end{aligned}
$$

Similar to instantaneous loads, the estimated SSCs were used with daily mean streamflow in equation 2 to estimate daily mean SSLs.

Summary statistics were computed for each of the regression equations and include a coefficient of determination $\left(\mathrm{R}^{2}\right)$, a root mean square error (RMSE), and a mean absolute error (MAE). $\mathrm{R}^{2}$ values range from 0 to 1 and estimate the proportion of variability explained by a regression model. As the $\mathrm{R}^{2}$ value approaches 1 , the models approach perfect correlation. RMSE is an estimator that quantifies the difference between values estimated by a model and the actual values that were measured. MAE is a metric for measuring how far estimated values deviate from measured values. As RMSE and MAE values approach 0 , the models approach perfect estimation (Helsel and Hirsch, 2002).

\section{Limitations in Estimating Suspended-Sediment Load from Streamflow}

Suspended-sediment loads estimated from log-linear regressions that relate SSC to streamflow provide a general characterization of the sources, timing, and quantity of SSLs in the study area. Limitations in the available suspendedsediment data and the effects of various assumptions might contribute to uncertainty in the development of the regression equations and the estimated SSLs produced from them.

The regression equations used to estimate SSCs incorporate historical and 2011-13 suspended-sediment sample data. Historical data from as early as 1966 to as late as 2004 are available from five sites ( 31 to 162 suspendedsediment samples per site) (table 1). The combination of these historical data with the 2011-13 suspended-sediment samples increases the robustness of the regressions by representing a wider range of hydrologic conditions for which suspendedsediment data were collected at the sites. The historical samples were collected during a wide range of streamflow conditions, including sampling during base-flow conditions. Most historical samples were collected on a routine schedule regardless of streamflow or sediment conditions; some were collected during storm runoff and represent different parts of storm hydrographs. In contrast, the 2011-13 samples were collected primarily during the rising limb to peak of the hydrograph during storm events, when SSLs often reach a maximum. Because the 2011-13 sampling plan intentionally targeted the rising limb to peak of the hydrograph during storm events, combination of the historical and 2011-13 data represents a wider range of hydrologic and antecedent conditions compared to those represented by the 2011-13 data alone. In addition to the historical samples potentially representing somewhat different hydrologic conditions compared to the 2011-13 samples, there are factors that might cause SSCs to change over time. These factors include (but are not limited to) (1) changes in the amount of urbanization and other changes in land use; (2) placement or removal of physical structures such as dams or levees; (3) implementation of best management practices within the contributing watershed; and (4) differences in sediment yields from land surfaces as a result of antecedent moisture conditions, time since last rainfall, rainfall intensity, and where the rainfall occurred within the basin (Glymph, 1951; Griffiths, 1981). At some sites, there are several years to several decades between the collection of historical and 2011-13 data. It was assumed that relations between streamflow and SSCs did not change at any of the sites because quantification of the factors that might cause SSCs to change over time was not possible when combining the historical and 2011-13 datasets. The combined dataset likely has a larger (and unquantified) degree of measurement uncertainty compared to the 2011-13 data because of the unknown magnitude of the factors previously mentioned in this paragraph that can affect SSC over time.

Another factor contributing to the estimated SSL uncertainty at two sites was that the sampling locations changed; the historical sampling locations were replaced with new sampling locations. Changes in the 2011-13 sampling locations at the SAR Falls City and Ecleto Runge sedimentsampling sites compared to their historical sampling locations at streamflow-gaging stations were made because the historical sediment-sampling sites were considered unsafe for the collection of sediment samples (the historical SAR Falls City and Ecleto Runge sampling sites continue to function as streamflow-gaging stations). No sediment samples were collected during 2011-13 at the historical SAR Falls City site because of safety considerations. Three samples were collected from January through March 2012 at the historical Ecleto Runge sampling site before this site was deemed unsafe 
for any additional sediment sampling. Replacement sampling sites were selected downstream as near as possible to the historical sampling sites and upstream from any tributaries. Land uses in the drainage areas upstream from the historical and 2011-13 sampling sites were similar, and no other notable factors were identified that might result in appreciable differences between the historical and 2011-13 suspended sediment concentrations. The SSLs in the study area are dominated by very fine suspended-sediment particle sizes that tend to remain in suspension during transport between the two sites, providing additional corroborating evidence that changes in SSLs between the historical and 2011-13 sampling sites were unlikely.

It was not practical to make streamflow measurements at the 2011-13 SAR Falls City and Ecleto Runge sampling sites; consequently, streamflows at these two sampling sites were estimated as the gaged streamflow measured at their respective upstream streamflow-gaging stations, taking into account the streamflow traveltime between the locations. To account for streamflow traveltime between the SAR Falls City gaging station and the 2011-13 sampling site (approximately 2 hours for streamflow greater than $1,000 \mathrm{ft}^{3} / \mathrm{s}$ ), streamflow measured at the gaging station 2 hours before the sample collection was used to represent streamflow conditions at the 2011-13 sample sites during stormflow events. Streamflow was not adjusted during base-flow conditions. Similarly, during sampling events at the Ecleto Runge site, gaged streamflow recorded 2 hours before the sampling event was used to represent streamflow conditions during the sample collection.

The regression of SSCs to streamflow data (eq. 4) collected at each of the sampling sites exhibits generally reasonable correlations between observed data and the regression estimates; however, during increased streamflow (typically, greater than the 80th percentile daily streamflow), SSCs tend to approach an upper limit (concentrations remain constant with increasing streamflow), which is likely attributable to watershed limits to the supply of available sediment in runoff (Porterfield, 1972; Gao, 2008). Therefore, the regression equations tend to oversimulate sediment concentrations, compared with observed SSC values, during increased streamflow. Also, extrapolation of the regression equations to simulate SSCs and SSLs for streamflow values that are greater than observed SSCs and SSLs during sample collection results in (possibly extreme) overestimates of SSCs and SSLs. During major runoff events, particularly for large events that were not sampled for suspended sediment, prediction of SSCs by regression would potentially result in overestimation of daily and event SSLs; therefore, to avoid overestimation of SSCs and SSLs, the regression-estimated SSCs (eq. 4) used to calculate daily SSLs at each sampling location (eq. 2) were limited (truncated) at a maximum value when the observed (sampled) SSCs approached the upper concentration limit.

\section{Estimating Suspended-Sediment Loads from Turbidity}

A correlation between turbidity and SSC has been documented in numerous reports for different geographic settings in the United States and in other parts if the world. Studies in the United States were done in the Pacific Northwest (Kunkle and Comer, 1971), Vermont (Beschta, 1980), Kansas (Christensen and others, 2000; Rasmussen and others, 2005, 2009), Oregon (Uhrich and Bragg, 2003; Bragg and Uhrich, 2010), the Chesapeake Bay area (Jastram and others, 2009), and Kentucky (Williamson and Crawford, 2011). Additional studies in other parts of the world include Indonesia (Brabben, 1981) and Australia (Gippel, 1989). By developing a regression equation from the relation of turbidity and SSC at a sampling site, a time series of SSCs can be estimated from a time series of turbidity data. Once the regression equation is developed, the time series of estimated SSCs can be used with the time series of streamflow to estimate a time series of SSLs (eq. 2). Because sediment transport is complex and dependent on many factors, regression equations for estimating SSCs are usually site specific and subject to change over time. Data collected over time can help verify change in sediment load, type, and source (Leopold, 1997; Rasmussen and others, 2009).

\section{Sediment Characteristics}

Sediment characteristics in the study area are described by comparing the results from various types of historical sediment data collected during 1966-94 with recent sediment data collected during 2011-13 (table 1). Sediment data were historically collected by the U.S. Geological Survey between 1966 and 2004 at five sites in the study area. Much of this historical data was collected during routine sampling efforts that typically characterized low-flow conditions, and only infrequently were larger flow events characterized. Most of the historical data also did not include particle-size distributions, and no bedload data were collected. During 2011-13, SSC and particle-size distribution were measured in samples collected at all sites, and bedload mass and particlesize distribution were measured in samples collected at six sites. The sediment data, along with streamflow information, were used to describe the sediment loads at sites during the various flow conditions. 


\section{Suspended-Sediment Concentration}

Measured SSCs in the 67 samples collected during 2011-13 ranged from $14 \mathrm{mg} / \mathrm{L}$ during base-flow conditions at the SAR Falls City site on August 19, 2011, to $4,480 \mathrm{mg} / \mathrm{L}$ during a stormflow event at the same site on January 26, 2012 (table 3). It should be noted that not all samples were collected during the same storm events, same routine events, or even same parts of the storm hydrographs; therefore, comparisons of concentrations between sites should be considered qualitative. Boxplots created using historical and 2011-13 SSC data from the sites are shown in figure 4. Varying amounts of historical SSC data were available for the SAR Elmendorf, SAR Falls City, Cibolo Falls City, Ecleto Runge, and SAR Goliad sites. No historical data were available for the Cibolo Selma, SAR 72, SAR McFaddin, or GR Tivoli sites.

A comparison of the boxplot for the historical data and the 2011-13 data from the SAR Elmendorf site demonstrates that the 2011-13 samples represent a wide range of SSCs, including some of the largest concentrations measured at the site. This is likely, in part, because the samples targeted stormflow events that typically elevate SSCs (Wood, 1977; VanSickle and Beschta, 1983; Glysson, 1987; Clark and others, 2013). The 2011-13 samples from the SAR Falls City, Cibolo Falls City, and SAR Goliad sites exhibited SSCs that plotted outside of the historical interquartile ranges for these sites. These results were not surprising because samples collected at these sites during 2011-13 were collected during historically low base-flow conditions that produce very low SSCs or were collected during stormflow events; whereas, the historical data were obtained possibly during different hydrologic conditions and potentially during different periods of the storm hydrograph. For example, it is not known if specific parts of the hydrograph, such as the rising limb or peak, were targeted during historical sampling as was the case for the 2011-13 samples. The SSCs from 2011-13 samples collected at the Ecleto Runge site all plotted at the upper end of the interquartile range or higher. Drought conditions were common during 2011-13 in the study area; therefore, base flow past the Ecleto Runge site was seldom, and the stream typically flowed only during storm events.

Table 3. Suspended-sediment data collected at sites in the San Antonio River Basin downstream from San Antonio, Texas, and at a site on the Guadalupe River downstream from the San Antonio River Basin, January 2011-May 2013, showing the percentage of sandsized and fine-sized particles in each sample.

[USGS, U.S. Geological Survey; $\mathrm{ft}^{3} / \mathrm{s}$, cubic feet per second; mg/L, milligrams per liter; mm, millimeter; *, grab sample]

\begin{tabular}{|c|c|c|c|c|c|c|}
\hline \multirow[b]{2}{*}{ Date } & \multirow[b]{2}{*}{ Time } & \multirow[b]{2}{*}{$\begin{array}{l}\text { Instantaneous } \\
\text { streamflow } \\
\left(\mathrm{ftt}^{3} / \mathrm{s}\right)\end{array}$} & \multirow[b]{2}{*}{$\begin{array}{l}\text { Suspended- } \\
\text { sediment } \\
\text { concentration } \\
\text { (mg/L) }\end{array}$} & \multirow[b]{2}{*}{$\begin{array}{l}\text { Instantaneous } \\
\text { suspended- } \\
\text { sediment load } \\
\text { (tons/day) }\end{array}$} & \multicolumn{2}{|c|}{ Suspended-sediment particle size } \\
\hline & & & & & $\begin{array}{l}\text { Less than } \\
0.0625 \mathrm{~mm} \\
\text { (percent) }\end{array}$ & $\begin{array}{l}\text { Equal to or } \\
\text { greater than } \\
0.0625 \mathrm{~mm} \\
\text { (percent) }\end{array}$ \\
\hline \multicolumn{7}{|c|}{ USGS 08181800 San Antonio River near Elmendorf, Tex. (SAR Elmendorf) } \\
\hline $1 / 27 / 2011$ & 0900 & 236 & 21 & 13 & 87 & 13 \\
\hline $5 / 13 / 2011$ & 1030 & 714 & 131 & 253 & 96 & 4 \\
\hline $6 / 22 / 2011$ & 1900 & 1,830 & 625 & 3,090 & 96 & 4 \\
\hline $10 / 9 / 2011$ & 1430 & 4,720 & 2,630 & 33,500 & 98 & 2 \\
\hline $1 / 25 / 2012$ & 1230 & 8,800 & 2,010 & 47,800 & 92 & 8 \\
\hline 9/14/2012 & 1300 & 5,360 & 1,160 & 16,800 & 99 & 1 \\
\hline \multicolumn{7}{|c|}{ USGS 08183550 San Antonio River at Highway 181 near Falls City, Tex. (SAR Falls City)² } \\
\hline $4 / 6 / 2011$ & 1230 & 171 & 37 & 17 & 95 & 5 \\
\hline $6 / 24 / 2011$ & 1000 & 1,000 & 930 & 2,511 & 98 & 2 \\
\hline $8 / 19 / 2011$ & 1100 & 52 & 14 & 2.0 & 93 & 7 \\
\hline $10 / 11 / 2011$ & 0930 & 2,880 & 1,990 & 15,474 & 94 & 6 \\
\hline $1 / 26 / 2012$ & 1400 & 3,590 & 2,390 & 23,200 & 96 & 4 \\
\hline
\end{tabular}


Table 3. Suspended-sediment data collected at sites in the San Antonio River Basin downstream from San Antonio, Texas, and at a site on the Guadalupe River downstream from the San Antonio River Basin, January 2011-May 2013, showing the percentage of sandsized and fine-sized particles in each sample.-Continued

[USGS, U.S. Geological Survey; $\mathrm{ft}^{3} / \mathrm{s}$, cubic feet per second; mg/L, milligrams per liter; mm, millimeter; *, grab sample]

\begin{tabular}{|c|c|c|c|c|c|c|}
\hline \multirow[b]{2}{*}{ Date } & \multirow[b]{2}{*}{ Time } & \multirow[b]{2}{*}{$\begin{array}{c}\text { Instantaneous } \\
\text { streamflow } \\
\left(\mathrm{ft}^{3} / \mathrm{s}\right)\end{array}$} & \multirow[b]{2}{*}{$\begin{array}{l}\text { Suspended- } \\
\text { sediment } \\
\text { concentration } \\
\text { (mg/L) }\end{array}$} & \multirow[b]{2}{*}{$\begin{array}{l}\text { Instantaneous } \\
\text { suspended- } \\
\text { sediment load } \\
\text { (tons/day) }\end{array}$} & \multicolumn{2}{|c|}{ Suspended-sediment particle size } \\
\hline & & & & & $\begin{array}{l}\text { Less than } \\
0.0625 \mathrm{~mm} \\
\text { (percent) }\end{array}$ & $\begin{array}{l}\text { Equal to or } \\
\text { greater than } \\
0.0625 \mathrm{~mm} \\
\text { (percent) }\end{array}$ \\
\hline \multicolumn{7}{|c|}{ USGS 08183550 San Antonio River at Highway 181 near Falls City, Tex. (SAR Falls City) ${ }^{2}$ —Continued } \\
\hline $1 / 26 / 2012$ & 1630 & 3,730 & 4,480 & 45,118 & 96 & 4 \\
\hline $5 / 12 / 2012$ & 1500 & 2,950 & 4,030 & 32,099 & 98 & 2 \\
\hline $7 / 12 / 2012$ & 1230 & 488 & 50 & 66 & 99 & 1 \\
\hline \multicolumn{7}{|c|}{ USGS 08185000 Cibolo Creek at Selma, Tex. (Cibolo Selma) } \\
\hline $9 / 17 / 2012$ & 0815 & 1.9 & 71 & 0.36 & 100 & 0 \\
\hline${ }^{1} 1 / 26 / 2011$ & 1350 & 54 & 37 & 5.4 & 55 & 45 \\
\hline $4 / 6 / 2011$ & 1350 & 30 & 18 & 1.5 & 96 & 4 \\
\hline $6 / 25 / 2011$ & 1300 & 62 & $53 *$ & 9.0 & 97 & 3 \\
\hline $1 / 26 / 2012$ & 0930 & 1,020 & 985 & 2,710 & 91 & 9 \\
\hline $2 / 19 / 2012$ & 1100 & 2,540 & 1,480 & 10,100 & 94 & 6 \\
\hline $3 / 21 / 2012$ & 1200 & 3,380 & 1,140 & 10,400 & 93 & 7 \\
\hline $9 / 30 / 2012$ & 1630 & 1,820 & 982 & 4,830 & 96 & 4 \\
\hline \multicolumn{7}{|c|}{ USGS 08186500 Ecleto Creek near Runge, Tex. (Ecleto Runge) ${ }^{3}$} \\
\hline $5 / 12 / 2012$ & 1030 & 397 & 510 & 547 & 93 & 7 \\
\hline \multicolumn{7}{|c|}{ USGS 08188060 San Antonio River at State Highway 72 near Runge, Tex. (SAR 72) } \\
\hline $6 / 25 / 2011$ & 1500 & 487 & 740 & 973 & 97 & 3 \\
\hline $8 / 19 / 2011$ & 0945 & 67 & 129 & 23 & 97 & 3 \\
\hline $10 / 11 / 2011$ & 1300 & 2,570 & 1,660 & 11,500 & 89 & 11 \\
\hline $1 / 27 / 2012$ & 1230 & 4,640 & 2,420 & 30,300 & 92 & 8 \\
\hline $3 / 22 / 2012$ & 1030 & 4,840 & 1,970 & 25,700 & 89 & 11 \\
\hline \multicolumn{7}{|c|}{ USGS 08188500 San Antonio River at Goliad, Tex. (SAR Goliad) } \\
\hline $1 / 26 / 2011$ & 1050 & 438 & 69 & 82 & 84 & 16 \\
\hline $4 / 6 / 2011$ & 0800 & 311 & 81 & 68 & 98 & 2 \\
\hline $6 / 25 / 2011$ & 2000 & 1,180 & 811 & 2,580 & 95 & 5 \\
\hline $10 / 13 / 2011$ & 0945 & 3,280 & 1,690 & 15,000 & 92 & 8 \\
\hline $1 / 28 / 2012$ & 1130 & 4,650 & 1,970 & 24,700 & 90 & 10 \\
\hline
\end{tabular}


Table 3. Suspended-sediment data collected at sites in the San Antonio River Basin downstream from San Antonio, Texas, and at a site on the Guadalupe River downstream from the San Antonio River Basin, January 2011-May 2013, showing the percentage of sandsized and fine-sized particles in each sample.-Continued

[USGS, U.S. Geological Survey; $\mathrm{ft}^{3} / \mathrm{s}$, cubic feet per second; mg/L, milligrams per liter; mm, millimeter; *, grab sample]

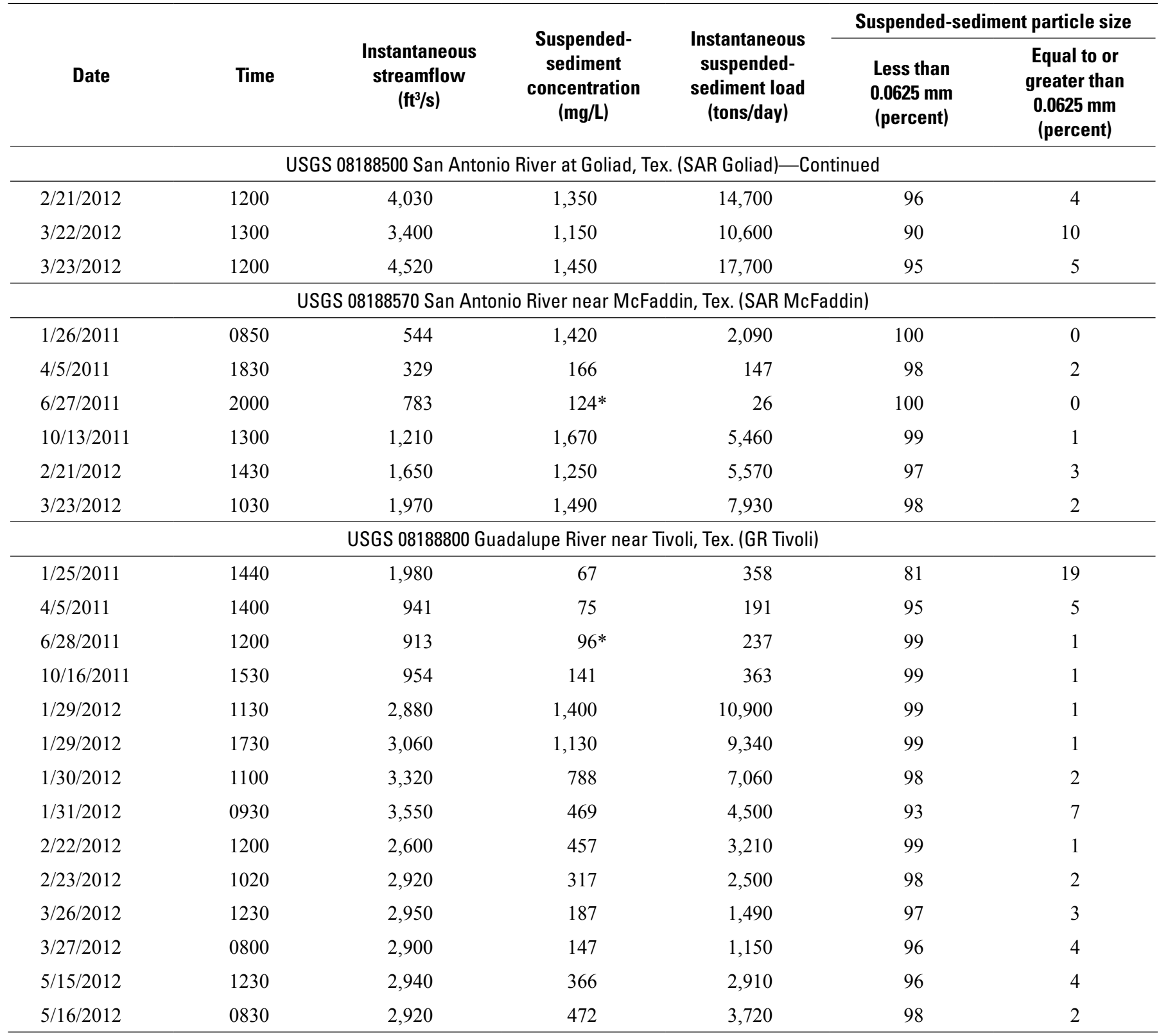

${ }^{1}$ Sample not included in analyses because of possible sampling issue but included in table for completeness of data set.

${ }^{2}$ For analysis, data collected at USGS station numbers 08183500 San Antonio River near Falls City, Tex., and 08183550 San Antonio River at Highway 181 near Falls City, Tex., were combined and reported under short name "SAR Falls City;" adjusted instantaneous streamflow from site 08183500 was reported for site 08183550

${ }^{3}$ For analysis, data collected at USGS station numbers 08186500 Ecleto Creek near Runge, Tex., and 08186550 Ecleto Creek at County Road 326 near Runge, Tex., were combined and reported under short name "Ecleto Runge;" adjusted instantaneous streamflow from site 08186500 was reported for site 08186550. 




Short name for sampling site (see table 1)

'Data collected at USGS station number 08183500 reported under short name "SAR Falls City."

"Data collected at USGS station number 08183550 reported under short name "SAR Falls City."

${ }^{3}$ Data collected at USGS station number 08186500 reported under short name "Ecleto Runge."

"Data collected at USGS station number 08186550 reported under short name "Ecleto Runge."

Figure 4. Distribution of suspended-sediment concentrations at sites in the San Antonio River Basin downstream from San Antonio, Texas, and at a site on the Guadalupe River downstream from the San Antonio River Basin, 1966-2013. 
The particle-size distribution data from the 2011-13 suspended-sediment samples were consistent with historical observations that the system is dominated by fine sediment particles less than $0.0625 \mathrm{~mm}$ in diameter. The elevated percentages of sand-sized or larger particles in the samples collected on April 4, 2011, at the SAR Elmendorf site and on January 26, 2011, at the Cibolo Falls City site were considered questionable especially at the streamflows at which the samples were collected. It is likely there was a problem with the sampling technique that allowed a small number of sand-sized or larger particles to enter the sampler during collection. These larger particles could easily skew the results at such low concentrations of suspended sediment, so these data were not used in any analyses for this report although they are shown in tables for completeness. Similarly, nine historical samples also were identified as potential outliers and were not used in the analyses from SAR Falls City, Cibolo Falls City, and SAR Goliad but are shown in appendix 1 for completeness. A summary of the sand/fine break data for the 2011-13 suspended-sediment samples indicates that, on average, about 94 percent of suspended-sediment particles in the samples were less than $0.0625 \mathrm{~mm}$ (silt and clay) (table 3). Furthermore, the data from the 50 samples for which a complete sediment-size analysis was performed indicate that an average of about 69 percent of the particles was less than $0.002 \mathrm{~mm}$, the smallest size range for which the samples were analyzed (table 4).

Table 4. Suspended-sediment data collected at sites in the San Antonio River Basin downstream from San Antonio, Texas, and at a site on the Guadalupe River downstream from the San Antonio River Basin, January 2011-May 2013, showing complete distribution of particle size for each sample.

[f³ 3 s, cubic feet per second; mm, millimeter; USGS, U.S. Geological Survey; --, no data]




Table 4. Suspended-sediment data collected at sites in the San Antonio River Basin downstream from San Antonio, Texas, and at a site on the Guadalupe River downstream from the San Antonio River Basin, January 2011-May 2013, showing complete distribution of particle size for each sample.-Continued

[USGS, U.S. Geological Survey; fťs, cubic feet per second; mm, millimeter; --, no data]

\begin{tabular}{|c|c|c|c|c|c|c|c|c|c|c|c|c|c|}
\hline \multirow[b]{2}{*}{$\begin{array}{c}\text { Sample } \\
\text { date }\end{array}$} & \multirow{2}{*}{$\begin{array}{l}\text { Sam- } \\
\text { ple } \\
\text { start } \\
\text { time }\end{array}$} & \multirow{2}{*}{$\begin{array}{c}\text { Instan- } \\
\text { taneous } \\
\text { stream- } \\
\text { flow } \\
\left(\mathbf{f t}^{3} / \mathbf{s}\right)\end{array}$} & \multicolumn{11}{|c|}{$\begin{array}{c}\text { Suspended-sediment diameter } \\
\text { (percentage) }\end{array}$} \\
\hline & & & $\begin{array}{c}\text { Less } \\
\text { than } \\
0.002 \\
\mathrm{~mm}\end{array}$ & $\begin{array}{c}\text { Less } \\
\text { than } \\
0.004 \\
\mathrm{~mm}\end{array}$ & $\begin{array}{c}\text { Less } \\
\text { than } \\
0.008 \\
\mathrm{~mm}\end{array}$ & $\begin{array}{c}\text { Less } \\
\text { than } \\
0.016 \\
\mathrm{~mm}\end{array}$ & $\begin{array}{c}\text { Less } \\
\text { than } \\
0.031 \\
\text { mm }\end{array}$ & $\begin{array}{c}\text { Less } \\
\text { than } \\
0.0625 \\
\text { mm }\end{array}$ & $\begin{array}{c}\text { Less } \\
\text { than } \\
0.125 \\
\mathrm{~mm}\end{array}$ & $\begin{array}{c}\text { Less } \\
\text { than } \\
0.25 \mathrm{~mm}\end{array}$ & $\begin{array}{c}\text { Less } \\
\text { than } \\
0.5 \mathrm{~mm}\end{array}$ & $\begin{array}{l}\text { Less } \\
\text { than } \\
1 \mathrm{~mm}\end{array}$ & $\begin{array}{l}\text { Less } \\
\text { than } \\
2 \mathrm{~mm}\end{array}$ \\
\hline \multicolumn{14}{|c|}{ USGS 08185000 Cibolo Creek at Selma, Tex. (Cibolo Selma) } \\
\hline 9/29/2012 & 915 & 37 & 93 & 99 & 99 & 100 & -- & -- & -- & -- & -- & -- & -- \\
\hline $5 / 25 / 2013$ & 1200 & 10,600 & 41 & 58 & 69 & 82 & 92 & 94 & 96 & 96 & 97 & 97 & 100 \\
\hline \multicolumn{14}{|c|}{ USGS 08186000 Cibolo Creek near Falls City, Tex. (Cibolo Falls City) } \\
\hline $3 / 21 / 2012$ & 1200 & 3,380 & 76 & 80 & 84 & 86 & 91 & 93 & 98 & 100 & -- & -- & -- \\
\hline $9 / 30 / 2012$ & 1630 & 1,820 & 71 & 77 & 82 & 87 & 92 & 96 & 99 & 99 & 100 & -- & -- \\
\hline \multicolumn{14}{|c|}{ USGS 08186500 Ecleto Creek near Runge, Tex. (Ecleto Runge)² } \\
\hline $1 / 26 / 2012$ & 1335 & 7 & 97 & 97 & 98 & 99 & 97 & 99 & 100 & -- & -- & -- & -- \\
\hline $2 / 19 / 2012$ & 1430 & 122 & 88 & 90 & 92 & 95 & 96 & 98 & 100 & -- & -- & -- & -- \\
\hline $3 / 21 / 2012$ & 1030 & 140 & 97 & 99 & 100 & -- & -- & -- & -- & -- & -- & -- & -- \\
\hline
\end{tabular}

USGS 08188060 San Antonio River at State Highway 72 near Runge, Tex. (SAR 72)

\begin{tabular}{rrrrrrrrrrrrrrrr}
\hline $6 / 25 / 2011$ & 1500 & 487 & 60 & 73 & 87 & 93 & 96 & 97 & 98 & 99 & 100 & -- & -- \\
$8 / 19 / 2011$ & 945 & 67 & -- & -- & -- & -- & -- & 97 & 99 & 100 & -- & -- & -- \\
$10 / 11 / 2011$ & 1300 & 2,570 & 57 & 63 & 69 & 76 & 83 & 89 & 97 & 99 & 100 & -- & -- \\
$1 / 27 / 2012$ & 1230 & 4,640 & 62 & 70 & 80 & 85 & 90 & 92 & 96 & 98 & 100 & -- & -- \\
$3 / 22 / 2012$ & 1030 & 4,840 & 68 & 75 & 73 & 82 & 87 & 89 & 90 & 91 & 100 & -- & -- \\
\hline
\end{tabular}

USGS 08188500 San Antonio River at Goliad, Tex. (SAR Goliad)

\begin{tabular}{llllllllllll}
\hline $6 / 25 / 2011$ & 2000 & 1,180 & 42 & 51 & 65 & 78 & 90 & 95 & 98 & 99 & 100 \\
$10 / 13 / 2011$ & 945 & 3,280 & 58 & 77 & 81 & 87 & 89 & 92 & 95 & 98 & 100 \\
$1 / 28 / 2012$ & 1130 & 4,650 & 72 & 78 & 82 & 87 & 88 & 90 & 92 & 96 & 100 \\
$2 / 21 / 2012$ & 1200 & 4,030 & 60 & 73 & 87 & 92 & 94 & 96 & 97 & 99 & 100
\end{tabular}


Table 4. Suspended-sediment data collected at sites in the San Antonio River Basin downstream from San Antonio, Texas, and at a site on the Guadalupe River downstream from the San Antonio River Basin, January 2011-May 2013, showing complete distribution of particle size for each sample.-Continued

[USGS, U.S. Geological Survey; ft³/s, cubic feet per second; mm, millimeter; --, no data]

\begin{tabular}{|c|c|c|c|c|c|c|c|c|c|c|c|c|c|}
\hline \multirow[b]{2}{*}{$\begin{array}{l}\text { Sample } \\
\text { date }\end{array}$} & \multirow{2}{*}{$\begin{array}{l}\text { Sam- } \\
\text { ple } \\
\text { start } \\
\text { time }\end{array}$} & \multirow{2}{*}{$\begin{array}{c}\text { Instan- } \\
\text { taneous } \\
\text { stream- } \\
\text { flow } \\
\left(\mathrm{ft}^{3} / \mathbf{s}\right)\end{array}$} & \multicolumn{11}{|c|}{$\begin{array}{l}\text { Suspended-sediment diameter } \\
\text { (percentage) }\end{array}$} \\
\hline & & & $\begin{array}{c}\text { Less } \\
\text { than } \\
0.002 \\
\text { mm }\end{array}$ & $\begin{array}{c}\text { Less } \\
\text { than } \\
0.004 \\
\text { mm }\end{array}$ & $\begin{array}{c}\text { Less } \\
\text { than } \\
0.008 \\
\mathrm{~mm}\end{array}$ & $\begin{array}{c}\text { Less } \\
\text { than } \\
0.016 \\
\mathrm{~mm}\end{array}$ & $\begin{array}{c}\text { Less } \\
\text { than } \\
0.031 \\
\text { mm }\end{array}$ & $\begin{array}{c}\text { Less } \\
\text { than } \\
0.0625 \\
\text { mm }\end{array}$ & $\begin{array}{c}\text { Less } \\
\text { than } \\
0.125 \\
\text { mm }\end{array}$ & $\begin{array}{c}\text { Less } \\
\text { than } \\
0.25 \mathrm{~mm}\end{array}$ & $\begin{array}{c}\text { Less } \\
\text { than } \\
0.5 \mathrm{~mm}\end{array}$ & $\begin{array}{l}\text { Less } \\
\text { than } \\
1 \mathrm{~mm}\end{array}$ & $\begin{array}{l}\text { Less } \\
\text { than } \\
2 \mathrm{~mm}\end{array}$ \\
\hline $3 / 22 / 2012$ & 1300 & 3,400 & 69 & 75 & 78 & 82 & 87 & 90 & 94 & 98 & 100 & -- & -- \\
\hline $3 / 23 / 2012$ & 1200 & 4,520 & 81 & 84 & 88 & 90 & 92 & 95 & 96 & 98 & 100 & -- & -- \\
\hline \multicolumn{14}{|c|}{ USGS 08188570 San Antonio River near McFaddin, Tex. (SAR McFaddin) } \\
\hline \multicolumn{14}{|c|}{ USGS 08188800 Guadalupe River near Tivoli, Tex. (GR Tivoli) } \\
\hline $6 / 28 / 2011$ & 1200 & 913 & -- & -- & -- & -- & -- & 99 & 100 & -- & -- & -- & -- \\
\hline $10 / 16 / 2011$ & 1530 & 954 & 72 & 80 & 84 & 91 & 95 & 99 & 100 & -- & -- & -- & -- \\
\hline $1 / 30 / 2012$ & 1100 & 3,320 & 82 & 88 & 91 & 95 & 95 & 98 & 99 & 100 & -- & -- & -- \\
\hline $1 / 31 / 2012$ & 930 & 3,550 & 74 & 79 & 82 & 85 & 90 & 93 & 96 & 99 & 100 & -- & -- \\
\hline $2 / 22 / 2012$ & 1200 & 2,600 & 82 & 88 & 91 & 96 & 98 & 99 & 99 & 100 & -- & -- & -- \\
\hline $5 / 16 / 2012$ & 830 & 2,920 & 81 & 95 & 98 & 98 & 98 & 98 & 99 & 100 & -- & -- & -- \\
\hline
\end{tabular}

${ }^{1}$ For analysis, data collected at USGS station numbers 08183500 San Antonio River near Falls City, Tex., and 08183550 San Antonio River at Highway 181 near Falls City, Tex., were combined and reported under short name "SAR Falls City;" adjusted instantaneous streamflow from site 08183500 was reported for site 08183550

${ }^{2}$ For analysis, data collected at USGS station numbers 08186500 Ecleto Creek near Runge, Tex., and 08186550 Ecleto Creek at County Road 326 near Runge, Tex., were combined and reported under short name "Ecleto Runge;" adjusted instantaneous streamflow from site 08186500 was reported for site 08186550 


\section{Bedload}

The mass from the 22 bedload samples collected during 2011-13 ranged from $12 \mathrm{~g}$ at the site furthest downstream (GR Tivoli) during base-flow conditions on April 5, 2011, to $8,900 \mathrm{~g}$ at the SAR Goliad site during a stormflow event on January 28, 2012 (table 5). The data from the particle-size analysis for 10 bedload samples collected during 2011-13 (table 6) indicated that, on average, about 91 percent of bedload was composed of sand-sized particles or smaller (less than $2 \mathrm{~mm}$ in size) with sediment in the $0.25-0.5-\mathrm{mm}$ size range accounting for a majority ( 51 percent, on average) of bedload. The bedload samples collected at upstream sample sites exhibited a wider range of sediment sizes and included greater percentages of larger particle sizes than those collected at downstream sites, which showed a very narrow and uniform particle-size distribution despite streamflow variation. This distribution is common in most river systems as sediment matures (becomes finer) as it is exposed to ongoing erosion as it moves through a basin. In addition, energy available for transporting sediment generally decreases as the stream approaches a delta and slope decreases.

\section{Sediment Loads}

\section{Instantaneous Suspended-Sediment Loads, Bedloads, and Total Loads}

Instantaneous SSLs computed from the 67 SSC samples collected during 2011-12 ranged from 0.36 tons per day at the Cibolo Selma site during base flow conditions on September 17, 2012, to 47,800 tons per day at the SAR Elmendorf site during a stormflow event on January 25, 2012 (table 3). Instantaneous bedload transport computed for the 22 samples collected during 2011-12 ranged from 0.15 tons per day at SAR Elmendorf during base-flow conditions on January 27, 2011, to 155 tons per day at site SAR Goliad during a stormflow event on January 28, 2012 (table 5). Instantaneous total sediment loads computed for the 21 samples for which both instantaneous SSL and instantaneous bedload were computed ranged from 13.1 tons per day at the SAR Elmendorf site on January 27, 2011, to 47,828 tons per day at the same site on January 25, 2012 (table 5). The percentage of instantaneous total sediment load that was bedload ranged from 0 to 7.2 percent, with bedload accounting for less than 1 percent of total sediment load in 13 of the 21 samples (table 5). The small percentage of bedload is not unexpected in the basin because the SSL is dominated by the fine sediment fraction.

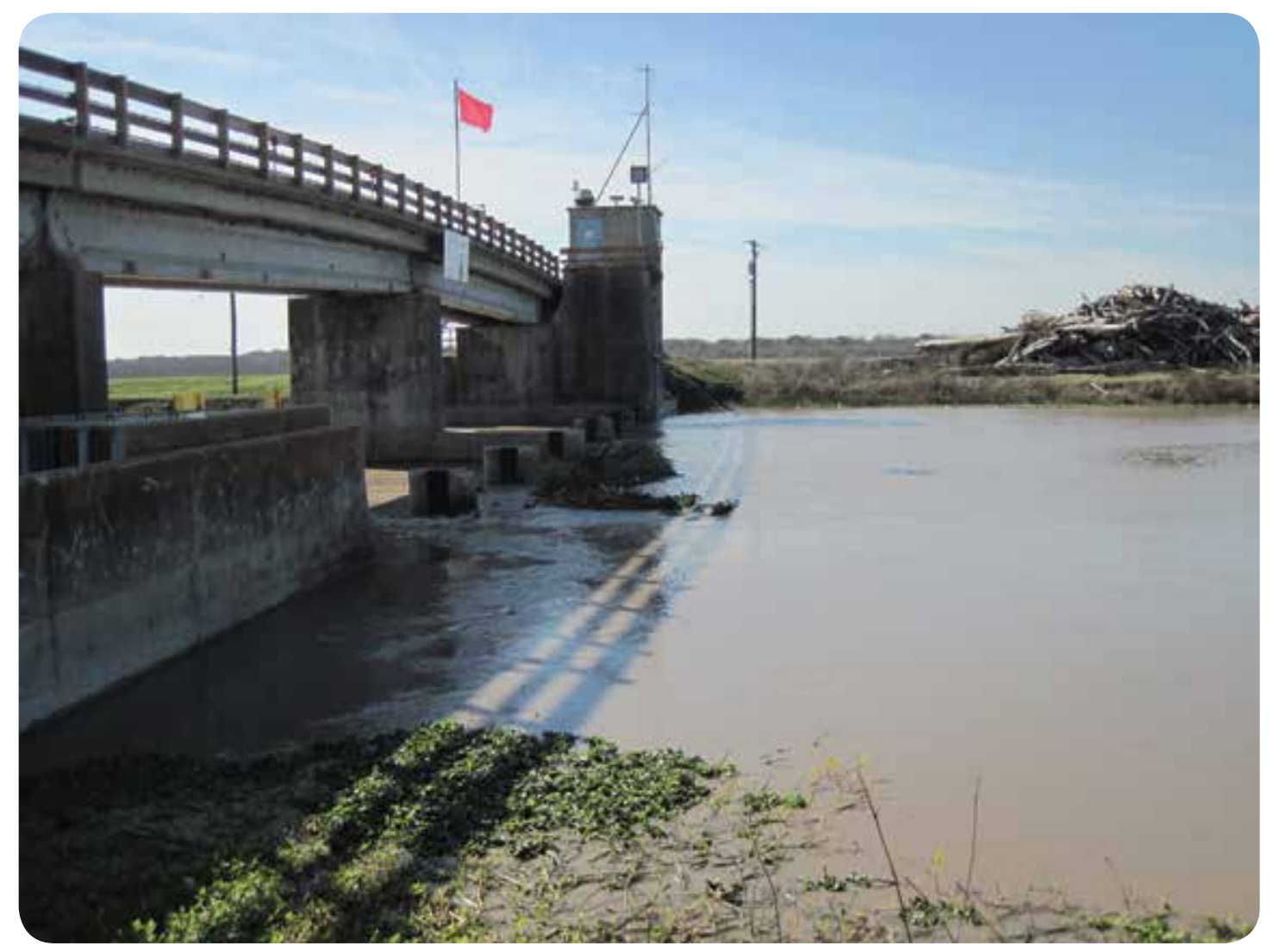

Guadalupe River near Tivoli, Texas. 
Table 5. Bedload mass and instantaneous bedload transport for samples collected at sites in the San Antonio River Basin downstream from San Antonio, Texas, and at a site on the Guadalupe River downstream from the San Antonio River Basin, January 2011-May 2013.

[SSL, suspended sediment load; CR, County Road; --, no data]

\begin{tabular}{|c|c|c|c|c|c|c|c|c|c|c|c|c|}
\hline \multirow{2}{*}{$\begin{array}{c}\text { U.S. Geo- } \\
\text { logical } \\
\text { Survey } \\
\text { station } \\
\text { number }\end{array}$} & \multirow[b]{2}{*}{$\begin{array}{l}\text { U.S. Geological Survey } \\
\text { station name }\end{array}$} & \multirow[b]{2}{*}{$\begin{array}{l}\text { Short name for } \\
\text { sampling site }\end{array}$} & \multirow[b]{2}{*}{$\begin{array}{l}\text { Sample } \\
\text { date }\end{array}$} & \multirow{2}{*}{$\begin{array}{c}\text { Bedload } \\
\text { sample } \\
\text { mass } \\
\text { (grams) }\end{array}$} & \multirow{2}{*}{$\begin{array}{l}\text { Composited } \\
\text { samples } \\
\text { in cross- } \\
\text { sectional } \\
\text { bedload } \\
\text { measurement } \\
\text { (number) }\end{array}$} & \multirow[b]{2}{*}{$\begin{array}{c}\text { Stream } \\
\text { width } \\
\text { (feet) }\end{array}$} & \multirow{2}{*}{$\begin{array}{c}\text { Rest } \\
\text { time on } \\
\text { bed for } \\
\text { bedload } \\
\text { sample } \\
\text { (seconds) }\end{array}$} & \multirow{2}{*}{$\begin{array}{c}\text { Instan- } \\
\text { taneous } \\
\text { bedload } \\
\text { transport } \\
\text { (tons } \\
\text { per day) }\end{array}$} & \multirow{2}{*}{$\begin{array}{c}\text { Instan- } \\
\text { taneous } \\
\text { SSL } \\
\text { (tons } \\
\text { per day) }\end{array}$} & \multirow{2}{*}{$\begin{array}{l}\text { Instanta- } \\
\text { neous } \\
\text { total } \\
\text { sediment } \\
\text { load } \\
\text { (tons } \\
\text { per day) }\end{array}$} & \multicolumn{2}{|c|}{$\begin{array}{l}\text { Percentage } \\
\text { of total load }\end{array}$} \\
\hline & & & & & & & & & & & $\begin{array}{l}\text { Sus- } \\
\text { pended- } \\
\text { sediment } \\
\text { load }\end{array}$ & Bedload \\
\hline 08181800 & $\begin{array}{l}\text { San Antonio River near } \\
\text { Elmendorf, Tex. }\end{array}$ & SAR Elmendorf & $1 / 27 / 2011$ & 32 & 40 & 44 & 90 & 0.15 & 13 & 13.1 & 98.9 & 1.1 \\
\hline 08181800 & $\begin{array}{l}\text { San Antonio River near } \\
\text { Elmendorf, Tex. }\end{array}$ & SAR Elmendorf & $4 / 7 / 2011$ & 112 & 40 & 36 & 120 & 0.32 & 26 & 26.3 & 98.8 & 1.2 \\
\hline 08181800 & $\begin{array}{l}\text { San Antonio River near } \\
\text { Elmendorf, Tex. }\end{array}$ & SAR Elmendorf & $5 / 13 / 2011$ & 5,450 & 40 & 45 & 120 & 20 & 253 & 273 & 92.8 & 7.2 \\
\hline 08181800 & $\begin{array}{l}\text { San Antonio River near } \\
\text { Elmendorf, Tex. }\end{array}$ & SAR Elmendorf & $6 / 22 / 2011$ & 3,060 & 40 & 62 & 60 & 30 & 3,090 & 3,120 & 99.0 & 1.0 \\
\hline 08181800 & $\begin{array}{l}\text { San Antonio River near } \\
\text { Elmendorf, Tex. }\end{array}$ & SAR Elmendorf & $10 / 9 / 2011$ & 1,050 & 40 & 117 & 60 & 20 & 33,500 & 33,520 & 99.9 & 0.1 \\
\hline 08181800 & $\begin{array}{l}\text { San Antonio River near } \\
\text { Elmendorf, Tex. }\end{array}$ & SAR Elmendorf & $1 / 25 / 2012$ & 1,360 & 40 & 130 & 60 & 28 & 47,800 & 47,828 & 99.9 & 0.1 \\
\hline 08186000 & $\begin{array}{l}\text { Cibolo Creek near Falls } \\
\text { City, Tex. }\end{array}$ & Cibolo Falls City & $2 / 19 / 2012$ & 313 & 40 & 68 & 60 & 3.4 & 10,100 & 10,103 & 100 & 0 \\
\hline 08186500 & $\begin{array}{l}\text { Ecleto Creek near } \\
\text { Runge, Tex. }\end{array}$ & Ecleto Runge $^{2}$ & $2 / 19 / 2012$ & 277 & 32 & 31 & 60 & 1.7 & 389 & 391 & 99.6 & 0.4 \\
\hline 08186550 & $\begin{array}{l}\text { Ecleto Creek at CR } 326 \\
\text { near Runge, Tex. }\end{array}$ & Ecleto Runge $^{2}$ & $3 / 20 / 2012$ & 42 & 38 & 34 & 60 & 0.24 & 19 & 19.2 & 98.8 & 1.2 \\
\hline 08186550 & $\begin{array}{l}\text { Ecleto Creek at CR } 326 \\
\text { near Runge, Tex. }\end{array}$ & Ecleto Runge $^{2}$ & $5 / 12 / 2012$ & 3,280 & 40 & 52 & 120 & 14 & 547 & 561 & 97.6 & 2.4 \\
\hline 08188500 & $\begin{array}{l}\text { San Antonio River at } \\
\text { Goliad, Tex. }\end{array}$ & SAR Goliad & $6 / 25 / 2011$ & 1,440 & 38 & 65 & 60 & 16 & 2,580 & 2,596 & 99.4 & 0.6 \\
\hline 08188500 & $\begin{array}{l}\text { San Antonio River at } \\
\text { Goliad, Tex. }\end{array}$ & SAR Goliad & $8 / 18 / 2011$ & 105 & 40 & 60 & 120 & 0.50 & -- & -- & -- & -- \\
\hline
\end{tabular}


Table 5. Bedload mass and instantaneous bedload transport for samples collected at sites in the San Antonio River Basin downstream from San Antonio, Texas, and at a site on the Guadalupe River downstream from the San Antonio River Basin, January 2011-May 2013.—Continued

[SSL, suspended sediment load; CR, County Road; --, no data]

\begin{tabular}{|c|c|c|c|c|c|c|c|c|c|c|c|c|}
\hline \multirow{3}{*}{$\begin{array}{c}\text { U.S. Geo- } \\
\text { logical } \\
\text { Survey } \\
\text { station } \\
\text { number } \\
08188500\end{array}$} & \multirow[b]{2}{*}{$\begin{array}{l}\text { U.S. Geological Survey } \\
\text { station name }\end{array}$} & \multirow[b]{2}{*}{$\begin{array}{l}\text { Short name for } \\
\text { sampling site }\end{array}$} & \multirow[b]{2}{*}{$\begin{array}{l}\text { Sample } \\
\text { date }\end{array}$} & \multirow{2}{*}{$\begin{array}{c}\text { Bedload } \\
\text { sample } \\
\text { mass } \\
\text { (grams) }\end{array}$} & \multirow{2}{*}{$\begin{array}{l}\text { Composited } \\
\text { samples } \\
\text { in cross- } \\
\text { sectional } \\
\text { bedload } \\
\text { measurement } \\
\text { (number) }\end{array}$} & \multirow[b]{2}{*}{$\begin{array}{l}\text { Stream } \\
\text { width } \\
\text { (feet) }\end{array}$} & \multirow{2}{*}{$\begin{array}{c}\text { Rest } \\
\text { time on } \\
\text { bed for } \\
\text { bedload } \\
\text { sample } \\
\text { (seconds) }\end{array}$} & \multirow{2}{*}{$\begin{array}{l}\text { Instan- } \\
\text { taneous } \\
\text { bedload } \\
\text { transport } \\
\text { (tons } \\
\text { per day) }\end{array}$} & \multirow{2}{*}{$\begin{array}{c}\text { Instan- } \\
\text { taneous } \\
\text { SSL } \\
\text { (tons } \\
\text { per day) }\end{array}$} & \multirow{2}{*}{$\begin{array}{l}\text { Instanta- } \\
\text { neous } \\
\text { total } \\
\text { sediment } \\
\text { load } \\
\text { (tons } \\
\text { per day) }\end{array}$} & \multicolumn{2}{|c|}{$\begin{array}{l}\text { Percentage } \\
\text { of total load }\end{array}$} \\
\hline & & & & & & & & & & & $\begin{array}{l}\text { Sus- } \\
\text { pended- } \\
\text { sediment } \\
\text { load }\end{array}$ & Bedload \\
\hline & $\begin{array}{l}\text { San Antonio River at } \\
\text { Goliad, Tex. }\end{array}$ & SAR Goliad & $1 / 28 / 2012$ & 8,900 & 40 & 110 & 60 & 155 & 24,700 & 24,855 & 99.4 & 0.6 \\
\hline 08188800 & $\begin{array}{l}\text { Guadalupe River near } \\
\text { Tivoli, Tex. }\end{array}$ & GR Tivoli & $1 / 25 / 2011$ & 485 & 40 & 127 & 60 & 10 & 358 & 368 & 97.3 & 2.7 \\
\hline 08188800 & $\begin{array}{l}\text { Guadalupe River near } \\
\text { Tivoli, Tex. }\end{array}$ & GR Tivoli & $4 / 5 / 2011$ & 12 & 20 & 138 & 120 & 0.27 & 191 & 191 & 99.9 & 0.1 \\
\hline 08188800 & $\begin{array}{l}\text { Guadalupe River near } \\
\text { Tivoli, Tex. }\end{array}$ & GR Tivoli & $6 / 28 / 2011$ & 66 & 40 & 126 & 60 & 1.3 & 237 & 238 & 99.4 & 0.6 \\
\hline 08188800 & $\begin{array}{l}\text { Guadalupe River near } \\
\text { Tivoli, Tex. }\end{array}$ & GR Tivoli & $10 / 16 / 2011$ & 25 & 40 & 125 & 120 & 0.24 & 363 & 363 & 99.9 & 0.1 \\
\hline 08188800 & $\begin{array}{l}\text { Guadalupe River near } \\
\text { Tivoli, Tex. }\end{array}$ & GR Tivoli & $1 / 30 / 2012$ & 1,270 & 40 & 130 & 60 & 26 & 7,060 & 7,086 & 99.6 & 0.4 \\
\hline 08188800 & $\begin{array}{l}\text { Guadalupe River near } \\
\text { Tivoli, Tex. }\end{array}$ & GR Tivoli & $1 / 31 / 2012$ & 518 & 40 & 130 & 60 & 11 & 4,500 & 4,511 & 99.8 & 0.2 \\
\hline 08188800 & $\begin{array}{l}\text { Guadalupe River near } \\
\text { Tivoli, Tex. }\end{array}$ & GR Tivoli & $2 / 22 / 2012$ & 425 & 40 & 132 & 60 & 8.9 & 3,210 & 3,219 & 99.7 & 0.3 \\
\hline 08188800 & $\begin{array}{l}\text { Guadalupe River near } \\
\text { Tivoli, Tex. }\end{array}$ & GR Tivoli & $3 / 26 / 2012$ & 735 & 40 & 130 & 60 & 15 & 1,490 & 1,505 & 99.0 & 1.0 \\
\hline 08188800 & $\begin{array}{l}\text { Guadalupe River near } \\
\text { Tivoli, Tex. }\end{array}$ & GR Tivoli & $5 / 15 / 2012$ & 641 & 40 & 130 & 120 & 6.6 & 2,910 & 2,917 & 99.8 & 0.2 \\
\hline
\end{tabular}

${ }^{1}$ Instantaneous total sediment load is the sum of instantaneous bedload transport plus instantaneous SSL. Unrounded values are reported for the sum because rounding to three significant figures would result in 100 percent suspended-sediment load and 0 percent bedload at most of the sampling sites.

${ }^{2}$ Data collected at sites 08186500 and 08186550 were reported under sampling site short name "Ecleto Runge." 
Table 6. Bedload particle-size distribution for samples collected at sites in the San Antonio River Basin downstream from San Antonio, Texas, and at a site on the Guadalupe River downstream from the San Antonio River Basin, January 2011-May 2013.

[USGS, U.S. Geological Survey; mm, millimeter; --, no data; CR, County Road]

\begin{tabular}{|c|c|c|c|c|c|c|c|c|c|c|c|c|c|c|}
\hline \multirow[b]{2}{*}{$\begin{array}{l}\text { USGS } \\
\text { station } \\
\text { number }\end{array}$} & \multirow[b]{2}{*}{$\begin{array}{c}\text { USGS } \\
\text { station name }\end{array}$} & \multirow[b]{2}{*}{$\begin{array}{l}\text { Short name for } \\
\text { sampling site } \\
\text { (table 1) }\end{array}$} & \multirow[b]{2}{*}{$\begin{array}{l}\text { Sample } \\
\text { date }\end{array}$} & \multirow[b]{2}{*}{$\begin{array}{c}\text { Sample } \\
\text { start } \\
\text { time }\end{array}$} & \multicolumn{10}{|c|}{$\begin{array}{l}\text { Bedload sediment diameter } \\
\text { (percentage) }\end{array}$} \\
\hline & & & & & $\begin{array}{l}\text { Less } \\
\text { than } \\
0.0625 \\
\text { mm }\end{array}$ & $\begin{array}{l}\text { Less } \\
\text { than } \\
0.125 \\
\text { mm }\end{array}$ & $\begin{array}{l}\text { Less } \\
\text { than } \\
0.25 \\
\mathrm{~mm}\end{array}$ & $\begin{array}{l}\text { Less } \\
\text { than } \\
0.5 \mathrm{~mm}\end{array}$ & $\begin{array}{l}\text { Less } \\
\text { than } \\
1 \mathrm{~mm}\end{array}$ & $\begin{array}{l}\text { Less } \\
\text { than } \\
2 \mathrm{~mm}\end{array}$ & $\begin{array}{l}\text { Less } \\
\text { than } \\
4 \mathrm{~mm}\end{array}$ & $\begin{array}{l}\text { Less } \\
\text { than } \\
8 \mathrm{~mm}\end{array}$ & $\begin{array}{c}\text { Less } \\
\text { than } \\
16 \mathrm{~mm}\end{array}$ & $\begin{array}{c}\text { Less } \\
\text { than } \\
32 \mathrm{~mm}\end{array}$ \\
\hline 08181800 & $\begin{array}{l}\text { San Antonio River near } \\
\text { Elmendorf, Tex. }\end{array}$ & SAR Elmendorf & $1 / 25 / 2012$ & 1330 & 0 & 1 & 2 & 18 & 56 & 86 & 96 & 99 & 100 & -- \\
\hline 08186000 & $\begin{array}{l}\text { Cibolo Creek near Falls } \\
\text { City, Tex. }\end{array}$ & Cibolo Falls City & $2 / 19 / 2012$ & 1200 & 2 & 4 & 5 & 40 & 76 & 83 & 87 & 91 & 95 & 100 \\
\hline 08186500 & $\begin{array}{l}\text { Ecleto Creek near } \\
\text { Runge, Tex. }\end{array}$ & Ecleto Runge $^{1}$ & 2/19/2012 & 1530 & 0 & 1 & 2 & 33 & 76 & 91 & 95 & 96 & 100 & -- \\
\hline 08186550 & $\begin{array}{l}\text { Ecleto Creek at CR } 326 \\
\text { near Runge, Tex. }\end{array}$ & Ecleto Runge $^{1}$ & $3 / 20 / 2012$ & 1300 & 0 & 1 & 3 & 40 & 76 & 88 & 95 & 100 & -- & -- \\
\hline 08186550 & $\begin{array}{c}\text { Ecleto Creek at CR } 326 \\
\text { near Runge, Tex. }\end{array}$ & Ecleto Runge $^{1}$ & $5 / 12 / 2012$ & 1200 & 1 & 1 & 2 & 53 & 89 & 96 & 98 & 99 & 100 & -- \\
\hline 08188500 & $\begin{array}{l}\text { San Antonio River at } \\
\text { Goliad, Tex. }\end{array}$ & SAR Goliad & $1 / 28 / 2012$ & 1500 & 0 & 0 & 3 & 54 & 89 & 95 & 97 & 98 & 100 & -- \\
\hline 08188800 & $\begin{array}{l}\text { Guadalupe River near } \\
\text { Tivoli, Tex. }\end{array}$ & GR Tivoli & $1 / 31 / 2012$ & 1130 & 2 & 2 & 7 & 81 & 89 & 92 & 95 & 97 & 100 & -- \\
\hline 08188800 & $\begin{array}{l}\text { Guadalupe River near } \\
\text { Tivoli, Tex. }\end{array}$ & GR Tivoli & $2 / 22 / 2012$ & 1400 & 1 & 2 & 5 & 80 & 92 & 95 & 98 & 100 & -- & -- \\
\hline 08188800 & $\begin{array}{l}\text { Guadalupe River near } \\
\text { Tivoli, }\end{array}$ & GR Tivoli & $3 / 26 / 2012$ & 1430 & 2 & 2 & 10 & 83 & 92 & 95 & 97 & 99 & 100 & -- \\
\hline 08188800 & $\begin{array}{l}\text { Guadalupe River near } \\
\text { Tivoli, Tex. }\end{array}$ & GR Tivoli & $5 / 15 / 2012$ & 1400 & 1 & 2 & 6 & 73 & 81 & 85 & 91 & 100 & -- & -- \\
\hline
\end{tabular}

'Data collected at USGS station numbers 08186500 and 08186550 were reported under sampling site short name "Ecleto Runge." 


\section{Estimated Daily Suspended-Sediment Loads from Streamflow}

Daily SSLs were estimated using the SSC to streamflow regression equations for each site (fig. 5; table 7; appendix 2). The regression equations and summary statistics are listed in table 7, and the residuals were approximately uniformly distributed. The estimated daily SSLs for each of the sites indicated that during 2011-12, the majority of the SSL in the basin originated upstream from the SAR Elmendorf site. The estimated average daily SSL was 237 tons per day at the SAR Elmendorf site and 454 tons per day at the SAR Goliad site during 2011-12. Downstream from the SAR Elmendorf site is the SAR Falls City site, where the estimated average daily SSL was 332 tons per day (table 7). This might be expected given that the majority of the streamflow at the SAR Falls City site originates upstream from the SAR
Elmendorf site. Note that the estimated SSLs during 2011-12 at the SAR Elmendorf and SAR Falls City sites were based on independent streamflow measurements and independent SSCs measurements at the respective sites, indicating that the regression method used for estimating loads produces consistent results. Because the Cibolo Selma site often did not flow, the estimated average daily SSL at Cibolo Falls City (57 tons per day) likely originates from within the study watershed, except during large stormflow events when there is streamflow at the Cibolo Selma site. During 2011-12, Ecleto Runge had the lowest SSL of 9 tons per day, which is expected because it drains a smaller watershed and streamflow generally only occurs during storm events. Regression analyses were not performed and SSLs were not estimated for the SAR 72, SAR McFaddin, and GR Tivoli sites because the relatively small number of data available for these sites represents only a limited range of hydrologic conditions.

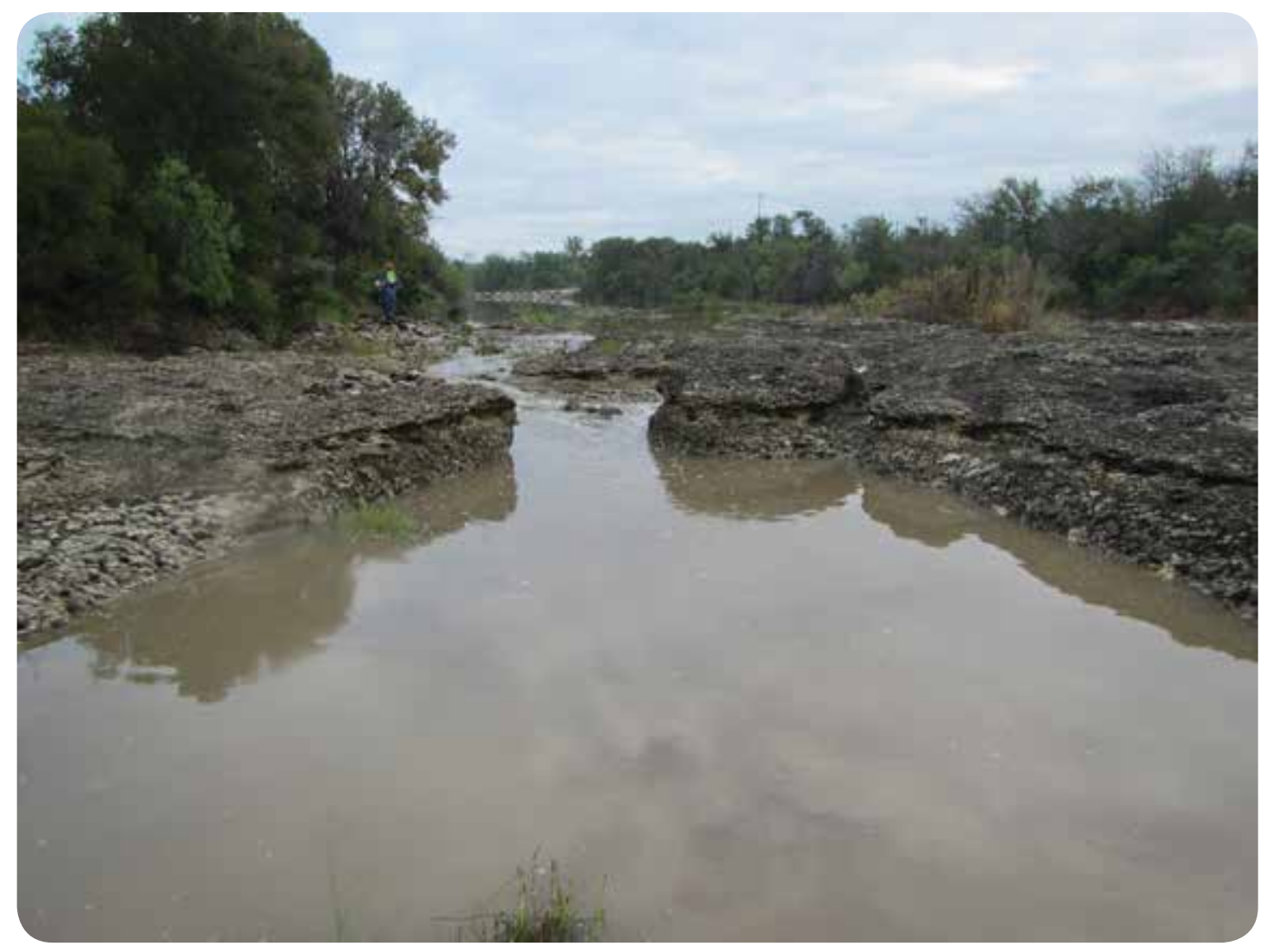

Cibolo Creek at Selma, Texas. 

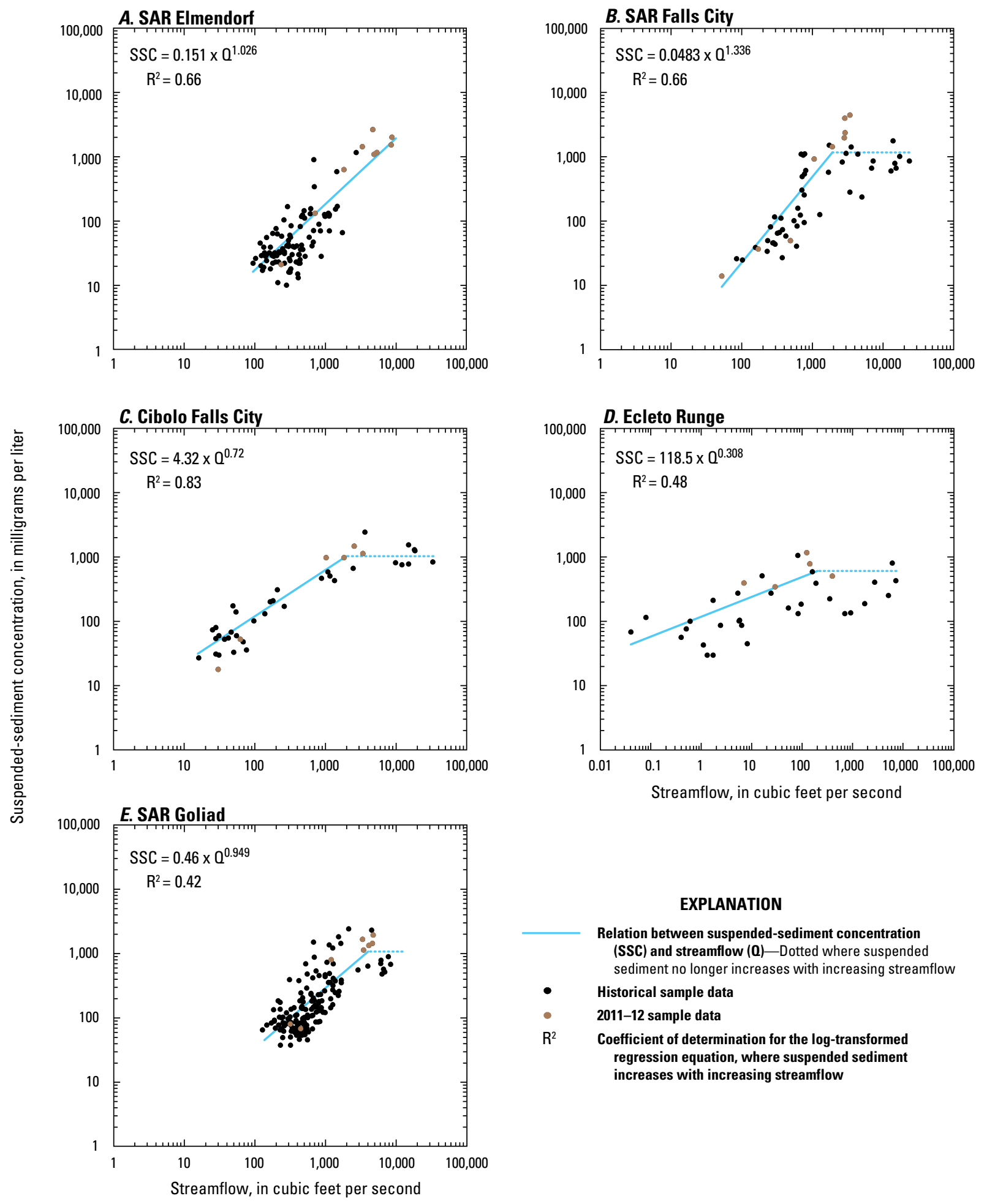

Note: Short names for sampling sites (table 1) are listed above the upper left corners of figures $5 \mathrm{~A}-5 \mathrm{E}$.

For analysis, data collected at USGS station numbers 08183500 and 08183550 were combined and reported under short name "SAR Falls City."

For analysis, data collected at USGS station numbers 08186500 and 08186550 were combined and reported under short name "Ecleto Runge."

Figure 5. Relations between suspended-sediment concentration and streamflow at sites $A$, SAR Elmendorf site (U.S. Geological Survey [USGS] station 08181800, San Antonio River near Elmendorf, Texas); B, SAR Falls City site (USGS station 08183500 San Antonio River near Falls City, Tex.); C, Cibolo Falls City site (USGS station 08186000, Cibolo Creek near Falls City, Tex.); D, Ecleto Runge site (USGS station 08186500, Ecleto Creek near Runge, Tex.); and E, SAR Goliad site (USGS station 08188500 San Antonio River at Goliad, Tex.). 
Table 7. Regression equations, average estimated suspended-sediment load, and summary statistics for suspended-sediment concentration regressions.

[Tex., Texas; SSC, suspended-sediment concentration, in milligrams per liter; Q, streamflow, in cubic feet per second; $\mathrm{ft}^{3} / \mathrm{s}$, cubic feet per second]

\begin{tabular}{|c|c|c|c|c|c|c|c|c|c|c|c|}
\hline $\begin{array}{l}\text { U.S. } \\
\text { Geologi- } \\
\text { cal Survey } \\
\text { station } \\
\text { number }\end{array}$ & $\begin{array}{l}\text { U.S. Geological Survey } \\
\text { station name }\end{array}$ & $\begin{array}{c}\text { Short name } \\
\text { of sampling } \\
\text { site } \\
\text { (table 1) }\end{array}$ & $\begin{array}{l}\text { Suspended- } \\
\text { sediment } \\
\text { concentration } \\
\text { to streamflow } \\
\text { regression equation' }\end{array}$ & $\begin{array}{c}\text { Range of } \\
\text { streamflow } \\
\text { when linear } \\
\text { regression } \\
\text { is appli- } \\
\text { cable }^{2} \\
\left(\mathrm{ft}^{3} / \mathrm{s}\right)\end{array}$ & $\begin{array}{l}\text { Number } \\
\text { of mea- } \\
\text { sure- } \\
\text { ments } \\
\text { (n) }\end{array}$ & $\begin{array}{l}\text { Coeffi- } \\
\text { cient of } \\
\text { determi- } \\
\text { nation } \\
\left(R^{2}\right)\end{array}$ & $\begin{array}{l}\text { Mean } \\
\text { absolute } \\
\text { error } \\
\text { (MAE) }\end{array}$ & $\begin{array}{c}\text { Root } \\
\text { mean } \\
\text { square } \\
\text { error } \\
\text { (RMSE) }\end{array}$ & $\begin{array}{l}\text { Bias } \\
\text { cor- } \\
\text { rection } \\
\text { factor } \\
(\Phi)\end{array}$ & p-value & $\begin{array}{c}\text { Average } \\
\text { estimated } \\
\text { suspend- } \\
\text { ed-sedi- } \\
\text { ment load } \\
\text { (SSL) } \\
\text { during } \\
\text { 2011-12 } \\
\text { (tons/day) }\end{array}$ \\
\hline 8181800 & $\begin{array}{l}\text { San Antonio River near } \\
\text { Elmendorf, Tex. }\end{array}$ & $\begin{array}{l}\text { SAR } \\
\text { Elmendorf }\end{array}$ & $\mathrm{SSC}=0.151 \times \mathrm{Q}^{1.026}$ & $0-1,000$ & 104 & 0.66 & 0.25 & 0.31 & 1.27 & $<0.001$ & 237 \\
\hline $\begin{array}{l}8183500 \\
\text { and } \\
8183550\end{array}$ & $\begin{array}{l}\text { San Antonio River near Falls } \\
\text { City, Tex., and San Antonio } \\
\text { River at Highway } 181 \text { near } \\
\text { Falls City, Tex. }\end{array}$ & $\begin{array}{l}\text { SAR Falls } \\
\text { City }^{3}\end{array}$ & $\mathrm{SSC}=0.0483 \times \mathrm{Q}^{1.336}$ & $0-1,910$ & 38 & 0.66 & 0.27 & 0.33 & 1.32 & $<0.001$ & 332 \\
\hline 8186000 & $\begin{array}{l}\text { Cibolo Creek near Falls } \\
\text { City, Tex. }\end{array}$ & $\begin{array}{l}\text { Cibolo Falls } \\
\text { City }\end{array}$ & $\mathrm{SSC}=4.32 \times \mathrm{Q}^{0.72}$ & $0-2,000$ & 30 & 0.83 & 0.16 & 0.20 & 1.11 & $<0.001$ & 57 \\
\hline $\begin{array}{l}8186500 \\
\text { and } \\
08186550\end{array}$ & $\begin{array}{l}\text { Ecleto Creek near Runge, } \\
\text { Tex., and Ecleto Creek } \\
\text { at County Road } 326 \text { near } \\
\text { Runge, Tex. }\end{array}$ & $\begin{array}{l}\text { Ecleto } \\
\text { Runge }^{4}\end{array}$ & $\mathrm{SSC}=118.5 \times \mathrm{Q}^{0.308}$ & $0-200$ & 27 & 0.48 & 0.28 & 0.33 & 1.32 & $<0.001$ & 9 \\
\hline 8188500 & $\begin{array}{l}\text { San Antonio River at } \\
\text { Goliad, Tex. }\end{array}$ & SAR Goliad & $\mathrm{SSC}=0.46 \times \mathrm{Q}^{0.949}$ & $0-3,500$ & 149 & 0.42 & 0.22 & 0.28 & 1.20 & $<0.001$ & 454 \\
\hline
\end{tabular}

${ }^{1}$ Regression equations incorporate the bias correction factor.

${ }^{2}$ When streamflow exceeded the upper range limit, SSC was set to a constant value equal to the estimated SSC based on streamflow at the upper value of the range.

${ }^{3}$ For analysis, data collected at USGS station numbers 08183500 and 08183550 were combined and reported under short name "SAR Falls City."

${ }^{4}$ For analysis, data collected at USGS station numbers 08186500 and 08186550 were combined and reported under short name "Ecleto Runge." 


\section{Estimated Daily Suspended-Sediment Loads from Turbidity}

Turbidity was measured every 15 minutes at the SAR Elmendorf site from January 6, 2011, through September 30, 2013. With the exception of two increases in turbidity (July 11, 2012, and January 9, 2013), the turbidity measurements truncated near the upper limit of the turbidity probe at approximately $1,100-1,200 \mathrm{FNU}$. The daily mean turbidity values (computed from the 15 -minute turbidity values) at the SAR Elmendorf site ranged from 4.6 FNU on September 3, 2011, to 710 FNU on August 19, 2012 (fig. 6; appendix 3).

The data truncated by the limitations of the turbidity probe and issues with the DCP program likely caused daily mean turbidity values to be underestimated, especially during storm events.

Measured SSCs and turbidity data collected at the time of sampling were used to develop linear regressions at three sites (SAR Elmendorf, SAR Goliad, and GR Tivoli) to be used for estimating SSCs based on turbidity values (fig. 7). Regressions were not developed at the other sites because too few samples were collected at those sites. The strong relation between SSC and turbidity established for the three sites $\left(\mathrm{R}^{2} 0.93\right.$ to 0.96 ) indicates the estimated SSC, used with a time-series of streamflow, could produce more accurate SSLs than using the $\mathrm{SSC}$ to streamflow regression relation $\left(\mathrm{R}^{2} 0.42-0.83\right)$.

The regression developed for the SAR Elmendorf site could be used to estimate a time series of SSCs from timeseries turbidity data collected at the SAR Elmendorf site (fig. 6). The time series of estimated SSCs could subsequently be paired with the time series of streamflow at the site to produce a time series of estimated SSLs. Although the regression could have been applied to the time series of turbidity data collected at the SAR Elmendorf site to produce a time series of estimated daily SSLs for this study, truncation problems within the turbidity data likely would have caused the SSLs to be substantially underestimated. Time-series turbidity data currently are not collected at the SAR Goliad and GR Tivoli sites, so time series of SSLs could not be estimated for those sites. Future suspended-sediment samples and corresponding turbidity values incorporated into these regressions will increase the accuracy of the regressions.



Figure 6. Daily mean turbidity from January 2011 through September 2013 at SAR Elmendorf site (U.S. Geological Survey station 08181800, San Antonio River near Elmendorf, Texas), in formazin nephelometric units (FNU). 




Note: Short names for sampling sites (table 1) are listed above the upper left corners of figures $7 \mathrm{~A}-7 \mathrm{C}$.

Figure 7. Relation between suspended-sediment concentrations and turbidity at $A$, SAR Elemendorf site (U.S. Geological Survey [USGS] station 08181800 San Antonio River near Elmendorf); $B$, SAR Goliad site (USGS station 08188500 San Antonio River at Goliad); and C, GR Tivoli site (USGS station 08188800 Guadalupe River near Tivoli, Texas).

\section{Summary}

To better understand sediment characteristics in the San Antonio River Basin downstream from San Antonio, the U.S. Geological Survey, in cooperation with the San Antonio River Authority and the Texas Water Development Board, collected and analyzed suspended-sediment, bedload, particle-size distribution, and turbidity data over a wide range of hydrologic conditions at sampling sites in the San Antonio River Basin downstream from San Antonio, Tex., and at one site on the Guadalupe River downstream from the San Antonio River Basin from January 2011 through May 2013 and combined that data with the available historical sediment data collected at the same sampling sites. Turbidity data collected in conjunction with suspended-sediment samples at a site were used to develop a regression that could be applied to timeseries turbidity data collected at the site to develop an estimate of time-series suspended-sediment concentrations (SSCs) at the site.

During 2011-13, suspended-sediment samples were collected at 10 sites for the analysis of SSC and particle size distribution. In addition, samples of bedload material were collected at six sites for the analysis of bedload mass and particle-size distribution. Samples were collected over a variety of hydrologic conditions ranging from a minimum streamflow of 1.9 cubic feet per second $\left(\mathrm{ft}^{3} / \mathrm{s}\right)$ at the Cibolo Selma site (Cibolo Creek at Selma, Tex.) on September 17, 2012 , to a maximum streamflow of $10,600 \mathrm{ft}^{3} / \mathrm{s}$ at the same site on May 25, 2013.

SSCs in 67 samples collected during 2011-13 ranged from 14 milligrams per liter $(\mathrm{mg} / \mathrm{L})$ during base-flow conditions at the SAR Falls City site (San Antonio River near Falls City, Tex.) on August 19, 2011, to 4,480 mg/L during a stormflow event at the same site on January 26, 2012. The samples collected during 2011-13 represent a wide range of SSCs, including some of the largest concentrations ever collected at some of the sites. Conversely, the majority of the historical samples collected at this site were routine samples that produced a relatively narrow range of concentrations. The data from the suspended-sediment samples collected during 2011-13 support historical observations that the system is dominated by the transport of fine sediment particles. On average, about 94 percent of suspended-sediment particles in all of the samples was less than 0.0625 millimeter $(\mathrm{mm})$ (silt and clay). Furthermore, the data from 50 samples for which a complete sediment-size analysis was performed indicate that an average of about 69 percent of the particles was less than $0.002 \mathrm{~mm}$, the smallest size range for which the samples were analyzed.

The mass from 22 bedload samples collected during 2011-13 ranged from 12 grams (g) at the site furthest downstream (GR Tivoli [Guadalupe River near Tivoli, Tex.]) during base-flow conditions on April 5, 2011, to 8,900 g at the SAR Goliad (San Antonio River near Goliad, Tex.) site during a stormflow event on January 28, 2012. The data from the particle-size analysis for 10 bedload samples collected during 
2011-13 indicate, on average, about 91 percent of sediment transported as bedload in the streams is sand-sized particles or smaller (less than $2 \mathrm{~mm}$ in size) with the greatest proportion (about 51 percent) being sediment in the $0.25-0.5-\mathrm{mm}$ size range.

Instantaneous suspended-sediment loads (SSLs) computed from 67 SSC samples collected during 2011-12 ranged from 0.36 tons per day at the Cibolo Selma site during base-flow conditions on September 17, 2012, to 47,800 tons per day at the SAR Elmendorf site (San Antonio River near Elmendorf, Tex.) during a stormflow event on January 25, 2012. Instantaneous bedload transport computed for the 22 samples collected during 2011-12 ranged from 0.15 tons per day at SAR Elmendorf during base-flow conditions on January 27, 2011, to 155 tons per day at site SAR Goliad during a stormflow event on January 28, 2012. Instantaneous total sediment loads computed for the 21 samples for which both SSL and bedload transport were computed ranged from 13.1 tons per day at the SAR Elmendorf site on January 27, 2011 , to 47,828 tons per day at the same site on January 25, 2012.

Daily SSLs were estimated using the SSC to streamflow regression equations for each site. The estimated daily SSLs for each of the sites indicated that during 2011-12, the majority of the SSL in the basin originated upstream from the SAR Elmendorf site. The estimated average daily SSL was 237 tons per day at the SAR Elmendorf site and 454 tons per day at the SAR Goliad site during 2011-12. Downstream from the SAR Elmendorf site is the SAR Falls City site, where the estimated average daily SSL was 332 tons per day. Because the Cibolo Selma site often did not flow, the estimated average daily SSL at Cibolo Falls City (Cibolo Creek near Falls City, Tex.) (57 tons per day) likely originates from within the study watershed, except during large stormflow events when there is streamflow at the Cibolo Selma site. During 2011-12, Ecleto Runge had the lowest SSL of 9 tons per day, which is expected because it drains a smaller watershed and streamflow generally only occurs during storm events.

Turbidity and SSC data collected at the SAR Elmendorf site were used in the development of a regression model for computing SSCs from instantaneous turbidity data. The regression could be used to estimate a time series of SSCs from time-series turbidity data collected at the SAR Elmendorf site. The time series of estimated SSCs could subsequently be paired with the time series of streamflow at the site to produce a time series of estimated SSLs. Although the regression could have been applied to the time series of turbidity data collected at the SAR Elmendorf site to produce a time series of estimated daily SSLs, truncation problems within the turbidity data likely would have caused the SSLs to be substantially underestimated. Future suspendedsediment samples and corresponding turbidity values incorporated into these regressions will increase the accuracy of the regressions.

\section{References}

Ashworth, J. B., and Hopkins, Janie, 1995, Major and minor aquifers of Texas: Texas Water Development Board Report $345,69 \mathrm{p}$.

ASTM International, 2007, D4410, in terminology for fluvial sediment, annual book of standards, water and environmental technology: West Conshohocken, Pa., ASTM International, $7 \mathrm{p}$.

Beschta, R.L., 1980, Turbidity and suspended sediment relationships, in Proceedings of Watershed Management Symposium, July 21-23, 1980, Boise Idaho: American Society of Civil Engineers, Irrigation and Drainage Division, p. 271-282.

Brabben, T.E., 1981, Use of turbidity monitors to access sediment yield in East Java, Indonesia: Proceedings of the IAHS Florence Symposium, June 22-26, 1981, Publication No. 133, p. 105-113.

Bragg, H.M., and Uhrich, M.A., 2010, Suspended-sediment budget for the North Santiam River Basin, Oregon, water years 2005-08: U.S. Geological Survey Scientific Investigations Report 2010-5038, 26 p.

Capel, P.D., and Larson, S.J., 1995, Evaluation of selected information on splitting devices for water samples: U.S. Geological Survey Water-Resources Investigations Report 95-4141, $103 \mathrm{p}$.

Christensen, V.G., Jian, Xiaodong, and Ziegler, A.C., 2000, Regression analysis and real-time water-quality monitoring to estimate constituent concentrations, loads, and yields in the Little Arkansas River, south-central Kansas, 1995-99: U.S. Geological Survey Water-Resources Investigations Report 00-4126, 36 p.

Clark, G.M., Fosness, R.L., and Wood, M.S., 2013, Sediment transport in the lower Snake and Clearwater River Basins, Idaho and Washington, 2008-11: U.S. Geological Survey Scientific Investigations Report 2013-5083, 56 p.

Davis, B.E., 2005, A guide to the proper selection and use of federally approved sediment and water-quality samplers: U.S. Geological Survey Open File Report 2005-1087, 20 p.

Edwards, T.K., and Glysson, G.D., 1999, Field methods for measurement of fluvial sediment: U.S Geological Survey Techniques of Water-Resource Investigations, book 3, chap. C2 (rev.), 89 p. (Also available at http://pubs.usgs.gov/twri/ twri3-c2/.)

Ellison, C.A., Savage, B.E., and Johnson, G.D., 2014, Suspended-sediment concentrations, loads, total suspended solids, turbidity, and particle-size fractions for selected rivers in Minnesota, 2007 through 2011: U.S. Geological Survey Scientific Investigations Report 2013-5205, 43 p. 
Galloway, J.M., Rus, D.L., and Alexander, J.S., 2013, Characteristics of sediment transport at selected sites along the Missouri River during the high-flow conditions of 2011: U.S. Geological Survey Scientific Investigations Report 2013-5006, $31 \mathrm{p}$.

Gao, Peng, 2008, Understanding watershed suspended sediment transport: Progress in Physical Geography, v. 32, no. 3, p. 243-263.

Gippel, C.J., 1989, Use of turbidimeters in suspended sediment research: Hydrobiologia, v. 176, no. 17, p. $465-480$.

Glymph, L.M., 1951, Relation of sedimentation to accelerated erosion in the Missouri River Basin: U.S. Department of Agriculture, Soil Conservation Service, Technical Paper 102 , p. 6 .

Glyson G.D., 1987, Sediment-transport curves: U.S. Geological Survey Open-File Report 87-218, 47 p.

Griffiths, G.A., 1981, Some suspended sediment yields from South Island catchments, New Zealand: Water Resources Bulletin 17, p. 662-671.

Guy, H.P., 1969, Laboratory theory and methods for sediment analysis: U.S. Geological Survey Techniques of WaterResources Investigations, book 5, chap. C1, 58 p. (Also available at http://pubs.usgs.gov/twri/twri5c1/.)

Helsel, D.R., and Hirsch, R.M., 2002, Statistical methods in water resources: U.S. Geological Survey Techniques of Water Resources Investigations, book 4, chap. A3, 522 p.

Horowitz, A. J., Hayes, T.S., Gray, J.R., and Capel, P.D., 1997, Selected laboratory tests of the shole-water sample splitting capabilities of the 14-liter churn and the teflon cone splitters: U.S. Geological Survey Office of Water Quality Technical Memorandum No. 97.06, 28 p.

Hubbell, D.W., 1964, Apparatus and techniques for measuring bedload: U.S. Geological Survey Water Supply Paper 1748, $74 \mathrm{p}$.

Jastram, J.D., Moyer, D.L., and Hyer, K.E., 2009, A comparison of turbidity-based and streamflow-based estimates of suspended-sediment concentrations in three Chesapeake Bay tributaries: U.S. Geological Survey Scientific Investigations Report 2009-5165, 37 p.

Kasmarek, M.C., and Robinson, J.L., 2004, Hydrogeology and simulation of ground-water flow and land-surface subsidence in the northern part of the Gulf Coast aquifer system, Texas: U.S. Geological Survey Scientific Investigations Report 2004-5102, 111 p.
Kemble, N.E., Hardesty, D.K., Ingersoll, C.G., Kunz, J.L., Sibley, P.K., Calhoun, D.L., Gilliom, R.J., Kuivila, K.M., Nowell, L.H., and Moran, P.W., 2013, Contaminants in stream sediments from seven United States metropolitan areas: Part II - Sediment toxicity to the amphipod Hyalella Azteca and the midge Chironomus dilutes: Archives of Environmental Contamination Toxicology, v. 64, p. 52-64.

Kolpin, D.W., Blazer, V.S., Gray, J.L., Focazio, M.J., Young, J.A., Alvarez, D.A., Iwanowicz, L.R., Foreman, W.T., Furlong, E.T., Speiran, G.K., Zaugg, S.D., Hubbard, L.E., Meyer, M.T., Sandstrom, M.W., and Barber, L.B., 2013, Chemical contaminants in water and sediment near fish nesting sites in the Potomac River Basin-Determining potential exposures to smallmouth bass (Micropterus dolomieu): Science of the Total Environment, v. 443, p. $700-716$.

Kunkle, S.H., and Comer, G.H., 1971, Estimating suspended sediment concentrations in streams by turbidity measurements: Journal of Soil and Water Conservation, v. 36 , p. $18-20$.

Leopold, L. B., 1997, Water, rivers, and creeks: Saulsalito,Calif., University Science Books, 183 p.

Lewis, Jack, 1996, Turbidity-controlled suspended sediment sampling for runoff-event load estimation: Water Resources Research, v. 32, no. 7, p. 2299-2310.

Lizárraga, J.S., and Ockerman, D.J., 2010, Simulation of streamflow, evapotranspiration, and groundwater recharge in the lower San Antonio River watershed, south-central Texas, 2000-2007: U.S. Geological Survey Scientific Investigations Report 2010-5027, 41 p.

Milliman, J.D., and Meade, R.H., 1983, World-wide delivery of river sediment to the oceans: Journal of Geology, v. 91, p. 1-21.

Moran, P.W., Calhoun, D.L., Nowell, L.H., Kemble, N.E., Ingersoll, C.G., Hladik, M.L., Kuivila, K.M., Falcone, J.A., and Gilliom, R.J., 2012, Contaminants in stream sediments from seven U.S. metropolitan areas-Data summary of a national pilot study: U.S. Geological Survey Scientific Investigations Report 2011-5092, 66 p.

Multi-Resolution Land Characteristics Consortium, 2013, National land cover database 2006: accessed August 1, 2013, at http://www.mrlc.gov/nlcd06_data.php.

National Oceanic and Atmospheric Administration, 2013, Climate data online: National Climatic Data Center, accessed December 27, 2013, at http://www.ncdc.noaa.gov/ oa/climate/stationlocator.html. 
Ockerman, D.J., and McNamara, K.C., 2003, Simulation of streamflow and estimation of streamflow compound loads in San Antonio River watershed, Bexar County, Texas, 1997-2001: U.S. Geological Survey Water-Resources Investigations Report 2003-4030, 44 p.

Porterfield, George, 1972, Computation of fluvial-sediment discharge: U.S. Geological Survey Techniques of WaterResources Investigations, book 3, chap. C3, 66 p.

Rantz, S.E., and others, 1982, Measurement and computation of streamflow: U.S. Geological Survey Water Supply Paper 2175, 2 v., 631 p.

Rasmussen, P.P., Gray, J.R., Glysson, G.D., and Ziegler, A.C., 2009, Guidelines and procedures for computing time-series suspended-sediment concentrations and loads from in-stream turbidity-sensor and streamflow data: U.S. Geological Survey Techniques and Methods, book 3, chap. C4, $52 \mathrm{p}$.

Rasmussen, T.J., Ziegler, A.C., and Rasmussen, P.P., 2005, Estimation of constituent concentrations, densities, loads, and yields on lower Kansas River, northeast Kansas, using regression models and continuous water-quality modeling, January 2000 through December 2003: U.S. Geological Survey Scientific Investigations Report 2005-5165, 117 p.

Ryder, P.D., 1996, Ground water atlas of the United StatesSegment 4, Oklahoma, Texas: U.S. Geological Survey Hydrologic Investigations Atlas 730-E, $30 \mathrm{p}$.

Shreve, E.A., and Downs, A.C., 2005, Quality-assurance plan for the analysis of fluvial sediment by the U.S. Geological Survey Kentucky Water Science Center Sediment Laboratory 2005: U.S. Geological Survey Open-File Report 2005-1230, $28 \mathrm{p}$.

Turnipseed, D.P., and Sauer, V.B., 2010, Discharge measurements at gaging stations: U.S. Geological Survey Techniques and Methods book 3, chap. A8, 87 p. (Also available at http://pubs.usgs.gov/tm/tm3-a8/.)

Uhrich, M.A., and Bragg, H.M., 2003, Monitoring instream turbidity to estimate continuous suspended-sediment loads and yields and clay-water volumes in the Upper North Santiam River Basin, Oregon, 1998-2000: U.S. Geological Survey Water-Resources Investigations Report 03-4098, $43 \mathrm{p}$.
U.S. Census Bureau, 2012, Texas cities lead Nation in population growth, Census Bureau reports: U.S. Census Bureau, accessed May 21, 2012, at http://www.census.gov/ newsroom/releases/archives/population/cb13-94.html.

U.S. Geological Survey, 2013, USGS water data for Texas: National Water Information System-Web interface at $\mathrm{http} / / /$ waterdata.usgs.gov/tx/nwis/nwis.

VanSickle, John, and Bescheta, R.L., 1983, Supply-based models of suspended sediment transport in streams: Water Resources Research, v. 19, p. 768-778.

Wagner, R.J., Boulger, R.W., Jr., Oblinger, C.J., and Smith, B.A., 2006, Guidelines and standard procedures for continuous water-quality monitors-Station operation, record computation, and data reporting: U.S. Geological Survey Techniques and Methods 1-D3, 51 p., 8 attachments.

Williamson, T. N., and Crawford, C. G., 2011. Estimation of suspended-sediment concentration from total suspended solids and turbidity data for Kentucky, 1978-1995: Journal of the American Water Resources Association, v. 47, no. 4, p. 739-749.

Wood, P.A., 1977, Controls of variation in suspended sediment concentration in the river Rother, West Sussex, England: Sedimentology, v. 24, p. 437-445.

Wood, P.J., and Armitage, P.D., 1997, Biological effects of fine sediment in the lotic environment: Environmental Management, v. 21, no. 2, p. 203-217.

Xylem Analytics, 2014a, YSI, Monitor, analyze, and protect the world's natural resources: accessed on February 10, 2014, at http://www.ysi.com/products.php.

Xylem Analytics, 2014b,, 6-Series multiparameter water quality sonde user manual: accessed on February 10, 2014, at https://www.ysi.com/media/pdfs/069300-YSI-6-SeriesManual-RevH.pdf.

Publishing support provided by

Lafayette Publishing Service Center

Information regarding water resources in Texas is available at http://tx.usgs.gov/ 

